\title{
Resveratrol and Depression in Animal Models: A Systematic Review of the Biological Mechanisms
}

\author{
Alyssa Moore, Joshua Beidler and Mee Young Hong * \\ School of Exercise and Nutritional Sciences, San Diego State University, San Diego, CA 92182, USA; \\ alyssamoore004@gmail.com (A.M.); beidler@gmail.com (J.B.) \\ * Correspondence: mhong2@sdsu.edu; Tel.: +1-619-594-2392; Fax: +1-619-594-6553
}

Received: 30 July 2018; Accepted: 28 August 2018; Published: 30 August 2018

\begin{abstract}
Depression is currently treated by pharmacotherapies that can elicit debilitating side effects for patients. Novel treatment options with limited side effects are currently being researched. Resveratrol is a polyphenol and phytoalexin found in the skins of grapes, red wine, Japanese knotweed, and peanuts. It has been studied extensively for its antioxidant and anti-inflammatory properties. Resveratrol has also gained attention for its neuroprotective properties. The aim of the review was to examine the mechanisms by which resveratrol reduces depressive behaviors in animal models. In total, 22 studies met the established criteria for final review. Behavioral aspects of depression were investigated using validated measures such as the forced swimming test, tail suspension test, sucrose preference test, and open field test. While many physical measures were taken, three main biological mechanisms were explored: Regulation of the hypothalamic-pituitary-adrenal axis; decreased inflammation; and increased Brain-Derived Neurotrophic Factor and neurogenesis. Based on these findings, resveratrol may be deemed an effective treatment for depression in animal models at doses between $10-80 \mathrm{mg} / \mathrm{kg} /$ day, although higher doses had the most significant effects. Future studies should examine the effects of resveratrol on depression in humans to determine the eligibility of resveratrol as a natural antidepressant with less severe side effects.
\end{abstract}

Keywords: resveratrol; depression; anxiety; stress; neurogenesis; BDNF; inflammation

\section{Introduction}

Depression, the most common mental disorder, affects over 300 million individuals worldwide [1]. Mental, neurological, and substance-use disorders make up 13\% of the global burden of disease, and depression is recognized as the third leading contributor. Depression has negative implications for individuals and their families and is associated with increased risk of mortality, lower income, higher unemployment, chronic disease, and other mental health disorders [2]. Furthermore, depression often leads to suicide, with 800,000 individuals dying due to suicide per year [1]. Depression also creates a major economic burden, which was estimated at \$210.5 billion in 2010 [3]. According to the Centers for Disease Control and Prevention (CDC), 11 percent of Americans over the age of 12 take antidepressant medication; from 2005 to 2008, antidepressant use increased $400 \%$ across all age groups [3,4].

While the pathogenesis of depression is known to include genetic, environmental, and psychosocial factors, the exact biological mechanisms remain to be elucidated [5]. Research on classical antidepressants reveals that multiple factors are involved and several brain regions are affected, helping to establish the mechanisms at play. These include dysregulation of the hypothalamic-pituitary-adrenal (HPA) axis, decreased neurogenesis, oxidative stress, and changes in serotonergic and adrenergic pathways [6]. 
Several antidepressant classes exist, including monoamine oxidase inhibitors (MAOIs), tricyclic antidepressants (TCAs), selective serotonin reuptake inhibitors (SSRIs), and serotonin and norepinephrine reuptake inhibitors (SNRIs) [7]. TCAs effectively inhibit the reuptake of serotonin, norepinephrine, and dopamine, but also affect other receptor systems and therefore have substantial adverse side effects. SSRIs reduce the reuptake of serotonin, and SNRIs reduce the reuptake of both serotonin and norepinephrine. SSRIs are now the most commonly prescribed antidepressants, as they have similar effectiveness as other medications while posing fewer severe side effects. Still, about half of patients experience a full remission, and the side effects of SSRIs, which include gastrointestinal issues, weight gain, sleep disturbances, and sexual dysfunction, can significantly impact quality of life [8]. Therefore, it is imperative to examine novel therapeutic agents with limited side effects for the treatment of depression.

There is growing evidence for the value of botanical compounds and other natural substances in the treatment of psychiatric disorders. In addition to resveratrol, plant components with possible antidepressant effects include anthocyanidins, catechins, and cocoa [9]. Resveratrol (3,5, $4^{\prime}$-trihydroxystilbene) is a phytoalexin and polyphenol found predominantly in the skins of red grapes, red wine, Japanese knotweed, and some nuts [10]. It has been studied extensively for its antioxidant, anti-inflammatory, and anticarcinogenic properties [11,12]. Resveratrol has also been implicated as a neuroprotective agent with the ability to increase neurogenesis, most notably in reducing Alzheimer's disease progression [13]. More recently, resveratrol has been examined as a potential aid to improve sleep quality [14], reduce fatigue [15], and ameliorate anxiety and depression [16]. While resveratrol has been shown to decrease depressive behaviors and biochemical markers associated with depression in animal models, few human studies exist to replicate these findings. The objective of the present review was to examine the effects of resveratrol on depressive behaviors in animal models through mechanisms that include regulation of the HPA axis, reduced inflammation and oxidative stress, increased neurogenesis, and increased monoamine production.

\section{Methods}

Articles were searched for using the databases PubMed Central and PsycInfo with the latest search date of August 2018. The phrases "resveratrol" and "depression" were entered into the search engine with the limitations of the years 2010 to 2018. This yielded 1859 articles from PubMed Central and 23 articles from PsycInfo. The titles of the articles were reviewed to determine if the study involved resveratrol and depression using an animal model. Based on this, 340 articles were chosen, and their abstracts were reviewed to inquire if they included resveratrol related to behavioral symptoms of depression or physical parameters of depression. Sixteen articles were read in depth to determine if they (a) included an animal model of depression treated with resveratrol and compared to a control and/or pharmaceutical antidepressant; (b) examined depressive behaviors using standardized protocols; and (c) explored the physiological mechanisms. Ten articles were established as eligible based on these methods, while 12 articles were chosen from the references of others, yielding a total of 22 articles for final review (Figure 1). The results of each study were reported based on mean differences with an alpha level of 0.01 or 0.05 based on the parameters set by each study author. Some studies had a broader focus that did not fit within the context of this review, and thus only those results that corresponded to our specific objectives were cited (Table 1). 
Table 1. Effects of Resveratrol on Behavioral and Clinical Outcomes of Depression.

\begin{tabular}{|c|c|c|c|c|c|}
\hline Author, Year & Animal Model & Intervention & Dosage/Route & $\begin{array}{c}\text { Behavioral Outcomes } \\
\text { w/RSV Txt }\end{array}$ & $\begin{array}{c}\text { Clinical Outcomes } \\
\text { w/RSV Txt }\end{array}$ \\
\hline $\begin{array}{c}\text { Ahmed and } \\
\text { colleagues, } 2014 \text { [17] }\end{array}$ & $\begin{array}{l}\text { reserpine-injected adult } \\
\text { male Wistar rats }\end{array}$ & $\begin{array}{l}\text { vehicle (saline + DMSO) } \\
\text { reserpine reserpine + } \\
\text { reserpine + RSV reserpine + } \\
\text { resperpine + FLX } \times 3 \text { days }\end{array}$ & RSV: 15, 30, 60 FLX: 24 & $\begin{array}{c}\uparrow \text { ambulation in OFT } \\
\text { a, a }(30 / 60) \downarrow \text { latency in } \\
\text { OOFT a,a,a }(15 / 30 / 60) \text { FST } \downarrow \\
\text { immobility time in FST } \\
\text { a,a,a }(15 / 30 / 60)\end{array}$ & $\begin{array}{c}\uparrow \text { NT levels: brain } 5-\mathrm{HT} \\
\mathrm{a}, \mathrm{a}, \mathrm{a}(15 / 30 / 60) \text {, dopamine } \\
\text { a,a,a }(15 / 30 / 60) \text {, and } \\
\text { Norepinephrine }^{\mathrm{a}(60)}\end{array}$ \\
\hline $\begin{array}{l}\text { Ali and colleagues, } \\
2015 \text { [18] }\end{array}$ & $\begin{array}{l}\text { CORT-injected male Swiss } \\
\text { albino mice }\end{array}$ & $\begin{array}{c}\text { CORT (con) CORT + RSV } \\
\text { CORT + FLX Vehicle (con) } \\
21 \text { days }\end{array}$ & $\begin{array}{l}\text { CORT: } 40 \text {, s.c. RSV: } 80 \text {, oral } \\
\text { FLX: } 15 \text {, oral Vehicle, } 0 \text {, oral }\end{array}$ & $\begin{array}{c}\uparrow \text { sucrose preference }{ }^{\mathrm{c}} \downarrow \\
\text { immobility time in FST }{ }^{\mathrm{b}} \downarrow \\
\text { immobility time in TST }\end{array}$ & $\begin{array}{c}\downarrow \text { serum CORT }^{\mathrm{b}} \uparrow \\
\text { hippocampal BDNF }^{\text {a }}\end{array}$ \\
\hline $\begin{array}{l}\text { Chen and colleagues, } \\
2017 \text { [19] }\end{array}$ & $\begin{array}{l}\text { LPS-injected male } \\
\text { ICR mice }\end{array}$ & $\begin{array}{l}\text { vehicle (saline) LPS LPS + } \\
\text { RSV tests after } 24 \mathrm{~h}\end{array}$ & RSV: 0.3, i.c.v. & $\begin{array}{l}\uparrow \text { sucrose preference }^{\mathrm{a}} \downarrow \\
\text { immobility time in FST }\end{array}$ & $\begin{array}{c}\downarrow \text { hippocampal } \\
\text { superoxide }^{\mathrm{a}} \downarrow \\
\text { hippocampal apoptosis }^{\text {a }} \\
\uparrow \text { hippocampal ATP } \\
\text { production }^{\text {a }} \uparrow \\
\text { hippocampal } \\
\text { mitochondrial } \\
\text { membrane potential }^{\text {a }}\end{array}$ \\
\hline $\begin{array}{l}\text { Finnel and colleagues, } \\
2017 \text { [20] }\end{array}$ & $\begin{array}{l}\text { social stress-exposed male } \\
\text { Sprague-Dawley rats \& } \\
\text { Long-Evans } \\
\text { retired breeders }\end{array}$ & $\begin{array}{l}\text { RSV + social stress Vehicle }+ \\
\text { social stress } 5 \text { days social } \\
\text { stress, Txt } 7 \text { days pre-social } \\
\text { stress \& during }\end{array}$ & $\begin{array}{c}\text { RSV: } 10, \text { 30, i.p. Vehicle: } \\
\text { 0, i.p. }\end{array}$ & $\uparrow$ sucrose preference $^{\mathrm{c}(30)}$ & 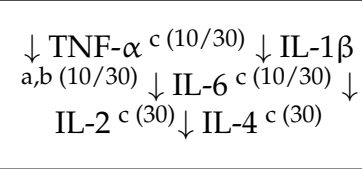 \\
\hline $\begin{array}{l}\text { Ge and colleagues, } \\
2013[21]\end{array}$ & $\begin{array}{l}\text { CUMS-exposed male } \\
\text { Sprague-Dawley rats }\end{array}$ & $\begin{array}{l}\text { CUMS + Vehicle CUMS + } \\
\text { RSV CUMS + FLX CUMS } 21 \\
\text { days, Txt days 14-21 }\end{array}$ & RSV: 15, i.p. FLX: 2, i.p. & $\begin{array}{c}\uparrow \text { sucrose preference }^{\mathrm{a}} \downarrow \\
\text { immobility time in FST }{ }^{\mathrm{c}} \downarrow \\
\text { immobility time in TST }\end{array}$ & $\begin{array}{l}\downarrow \text { serum } \text { CORT }^{\mathrm{c}} \downarrow \text { serum } \\
\text { MDA }^{\mathrm{c}} \sim \text { serum }^{\mathrm{CRH}}{ }^{\mathrm{d}}\end{array}$ \\
\hline $\begin{array}{l}\text { Ge and colleagues, } \\
2015 \text { [22] }\end{array}$ & $\begin{array}{l}\text { LPS-injected adult male } \\
\text { Kunming mice }\end{array}$ & $\begin{array}{l}\text { Vehicle (saline) Vehicle + } \\
\text { LPS RSV + Vehicle RSV } \\
\text { + LPS }\end{array}$ & RSV: 80, i.p. LPS: 0.83, i.p. & $\begin{array}{c}\downarrow \text { immobility time in FST } \\
\mathrm{b} \uparrow \text { swimming time in FST } \\
\mathrm{b} \downarrow \text { immobility time in } \\
\text { TST } \mathrm{a} \uparrow \text { sucrose preference } \\
\quad \mathrm{a} \sim \text { locomotor activity } \mathrm{d}\end{array}$ & $\begin{array}{c}\downarrow \text { hippocampal \& PFC } \\
\text { IL-1 } \beta^{\mathrm{a}} \downarrow \text { hippocampal } \\
\text { TNF- } \alpha^{\mathrm{a}} \downarrow \text { PFC TNF- } \alpha^{\mathrm{b}} \downarrow \\
\text { hippocampal \& PFC } \\
\text { pNF-кB p65 }{ }^{\mathrm{a}} \uparrow \text { PFC } \\
\text { pCREB } \uparrow \\
\text { hippocampal BDNF }\end{array}$ \\
\hline
\end{tabular}


Table 1. Cont.

\begin{tabular}{|c|c|c|c|c|c|}
\hline Author, Year & Animal Model & Intervention & Dosage/Route & $\begin{array}{c}\text { Behavioral Outcomes } \\
\text { w/RSV Txt }\end{array}$ & $\begin{array}{c}\text { Clinical Outcomes } \\
\text { w/RSV Txt }\end{array}$ \\
\hline $\begin{array}{c}\text { Ge and colleagues, } \\
2016[16]\end{array}$ & $\begin{array}{c}\text { SCH male } \\
\text { Sprague-Dawley rats }\end{array}$ & $\begin{array}{c}\mathrm{SCH}+\text { Vehicle SCH + RSV } \\
\mathrm{SCH}+\mathrm{LT} 4 \text { Txt post SCH for } \\
16 \text { days }\end{array}$ & RSV: 15 , i.g. LT4: $60 *$, i.g. & $\begin{array}{c}\uparrow \text { sucrose preference }^{\mathrm{b}} \uparrow \\
\text { locomotor activity }{ }^{\mathrm{a}} \downarrow \\
\text { immobility time in FST }{ }^{\mathrm{b}} \downarrow \\
\text { immobility time in TST }^{\mathrm{b}}\end{array}$ & 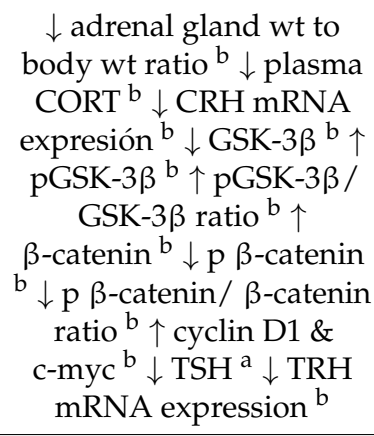 \\
\hline $\begin{array}{l}\text { Huang and colleagues, } \\
2013 \text { [23] }\end{array}$ & male ICR mice & RSV FLX RSV + piperine & $\begin{array}{c}\text { RSV: } 1.25,2.5,10,20,40, \\
\text { 160, oral } \\
\text { FLX: } 10 \text { i.p. } \\
\text { piperine: } 2.5 \text { i.p. }\end{array}$ & $\begin{array}{c}\downarrow \text { immobility time in FST } \\
\mathrm{a}, \mathrm{a}, \mathrm{a}, \mathrm{a}(2.5 / 10 / 40 / 160) \\
\downarrow \\
\text { immobility time in TST } \\
\mathrm{a}, \mathrm{a}, \mathrm{a}, \mathrm{a}(2.5 / 10 / 40 / 160) \\
\sim \text { locomotor activity }{ }^{\mathrm{d}} \downarrow \\
\text { reserpine-induced } \\
\text { hypothermia } \\
\mathrm{a}, \mathrm{a}, \mathrm{a}, \mathrm{a}, \mathrm{a}(1.25 / 2.5 / 5 / 10 / 20) \\
\text { ptosis }^{\mathrm{a}(20)}\end{array}$ & $\begin{array}{c}\uparrow 5-\mathrm{HT}^{\mathrm{a}, \mathrm{b}(10 / 20)} \\
\text { norepinephrine }{ }^{\mathrm{a}(20)}, \\
\text { dopamine }^{\mathrm{a}(20)} \text { in FC } \downarrow \\
\text { 5-HIAA/5-HT in FC } \mathrm{b}(20) \\
\downarrow \text { MAO-A in FC } \\
\text { a,b,b (5/10/20) and } \\
\text { hippocampus }{ }^{\mathrm{a}, \mathrm{b}(10 / 20)} \downarrow \\
\text { MAO-B in FC }{ }^{\mathrm{a}(20)}\end{array}$ \\
\hline $\begin{array}{c}\text { Hurley and } \\
\text { colleagues, } 2014 \text { [6] }\end{array}$ & $\begin{array}{l}\text { Adult male Wistar } \\
\text { kyoto rats }\end{array}$ & $\begin{array}{l}\text { RSV v Vehicle Txt } 20 \text { min } \\
\text { post-injection (acute) \& } \\
\text { 18-20 h post-injection } \\
\text { (chronic) } \times 7 \text { days }\end{array}$ & RSV: 0 (saline), 10, 40, i.p. & $\begin{array}{c}\downarrow \text { immobility time in FST } \\
\text { a,c (acute, 10/40) } \downarrow \\
\text { immobility time in FST } \\
\text { a,c (chronic, } 10 / 40) \sim \text { sucrose } \\
\text { preference } \mathrm{d} \text { (acute) } \uparrow \\
\text { sucrose preference } \\
\text { a,c (chronic, } 10 / 40) \\
\sim \text { locomotor activity } \\
\text { d (acute/chronic, 10/40) }\end{array}$ & $\begin{array}{c}\uparrow \text { hippocampal BDNF } \\
\text { b (10/40) } \sim \text { PFC BDNF } \\
\text { d (acute/chronic, } 10 / 40)\end{array}$ \\
\hline
\end{tabular}


Table 1. Cont.

\begin{tabular}{|c|c|c|c|c|c|}
\hline Author, Year & Animal Model & Intervention & Dosage/Route & $\begin{array}{c}\text { Behavioral Outcomes } \\
\text { w/RSV Txt }\end{array}$ & $\begin{array}{c}\text { Clinical Outcomes } \\
\text { w/RSV Txt }\end{array}$ \\
\hline $\begin{array}{l}\text { Kodali and colleagues, } \\
2015 \text { [24] }\end{array}$ & $\begin{array}{l}\text { Late/middle-age male } \\
\text { Fischer } 344 \text { rats }\end{array}$ & $\begin{array}{l}\text { RSV v Vehicle } 4 \text { weeks txt, } 4 \\
\text { weeks waiting period, } \\
\text { behavioral tests }\end{array}$ & RSV: 40, i.p. & $\downarrow$ immobility time in FST ${ }^{\text {a }}$ & 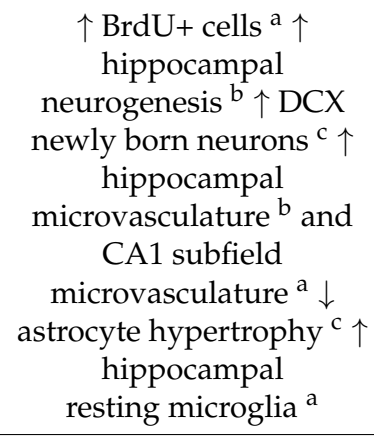 \\
\hline $\begin{array}{l}\text { Li and colleagues, } \\
2016 \text { [25] }\end{array}$ & $\begin{array}{l}\text { CORT-injected male } \\
\text { ICR mice }\end{array}$ & $\begin{array}{c}\text { CORT RSV FLX } \\
\text { Pioglitazone } \times 3 \text { weeks }\end{array}$ & $\begin{array}{l}\text { CORT: } 40 \text { s.c. RSV: } 50,100, \\
\text { oral FLX: } 20, \text { oral } \\
\text { pioglitazone: } 10, \text { oral }\end{array}$ & $\begin{array}{l}\uparrow \text { sucrose preference } \\
\text { b,c }(50 / 100) \downarrow \text { immobility } \\
\text { time in FST b,c (50/100) } \\
\sim \text { locomotor activity } \mathrm{d}\end{array}$ & $\downarrow$ serum CORT ${ }^{\mathrm{b}, \mathrm{b}(50 / 100)}$ \\
\hline $\begin{array}{l}\text { Liu and colleagues, } \\
2014 \text { [26] }\end{array}$ & $\begin{array}{l}\text { CUMS-exposed male } \\
\text { Wistar rats }\end{array}$ & $\begin{array}{l}\text { Vehicle RSV (80) DES (10) } \\
\text { CUMS + vehicle CUMS + } \\
\text { RSV }(20,40,80) \text { CUMS + } \\
\text { DES } \times 5 \text { weeks }\end{array}$ & $\begin{array}{c}\text { RSV: } 20,40,80 \text {, i.p. DES: } \\
\text { 10, i.p. } \\
\text { Vehicle: } 1 \% \text { ethanol, i.p. }\end{array}$ & $\begin{array}{c}\uparrow \text { sucrose preference } \\
\mathrm{a}, \mathrm{a}, \mathrm{b}(20 / 40 / 80) \downarrow \text { immobility } \\
\text { time in FST }{ }^{\mathrm{a}, \mathrm{a}(40 / 80) \uparrow} \\
\text { locomotor activity }^{\mathrm{a}(80)}\end{array}$ & $\begin{array}{c}\downarrow \text { serum CORT a (80) } \uparrow \\
\text { hippocampal BDNF b (80) } \\
\uparrow \text { amygdala BDNF } \\
\text { b,b (40/80) } \uparrow \text { hippocampal } \\
\text { and amygdala } \\
\text { pCREB } / \text { CREB ratio b,a (80) } \\
\uparrow \text { hippocampal pERK } \\
\text { a,b }(40 / 80) \uparrow \text { amygdala } \\
\text { pERK }^{\mathrm{a}, \mathrm{a}(40 / 80)}\end{array}$ \\
\hline $\begin{array}{l}\text { iu and colleagues, } \\
2014 \text { [27] }\end{array}$ & $\begin{array}{l}\text { CUMS-exposed male } \\
\text { Wistar rats }\end{array}$ & $\begin{array}{l}\text { Vehicle RSV CUMS + } \\
\text { vehicle CUMS + RSV } \\
\quad \times 5 \text { weeks }\end{array}$ & $\begin{array}{c}\text { vehicle ( } 1 \% \text { ethanol) RSV: } \\
80 \text { i.p. }\end{array}$ & $\begin{array}{c}\downarrow \text { escape latency in Morris } \\
\text { water maze } \mathrm{b} \uparrow \\
\text { exploration time in novel } \\
\text { object recognition test }^{\mathrm{a}}\end{array}$ & $\begin{array}{c}\downarrow \text { serum } \mathrm{CORT}^{\mathrm{a} \uparrow} \uparrow \mathrm{PFC} \\
\mathrm{BDNF}{ }^{\mathrm{a}} \uparrow \text { hippocampal } \\
\mathrm{BDNF} \text { a } \downarrow \text { hippocampal } \\
\text { and PFC } \mathrm{p} \text { CREB } / \mathrm{CREB} \\
\text { ratio }^{\mathrm{a}} \uparrow \mathrm{p} \text { ERK/ERK } \\
\text { ratio }^{\mathrm{a}}\end{array}$ \\
\hline
\end{tabular}


Table 1. Cont.

\begin{tabular}{|c|c|c|c|c|c|}
\hline Author, Year & Animal Model & Intervention & Dosage/Route & $\begin{array}{c}\text { Behavioral Outcomes } \\
\text { w/RSV Txt }\end{array}$ & $\begin{array}{c}\text { Clinical Outcomes } \\
\text { w/RSV Txt }\end{array}$ \\
\hline $\begin{array}{l}\text { Liu and colleagues, } \\
2016[5]\end{array}$ & $\begin{array}{l}\text { LPS-injected adult male } \\
\text { C57/BL6 mice }\end{array}$ & $\begin{array}{c}\text { Saline }+ \text { DMSO Saline + } \\
\text { RSV LPS + DMSO LPS + } \\
\text { RSV } \times 14 \text { days }\end{array}$ & RSV: 20, i.p. LPS: 1, i.p. & 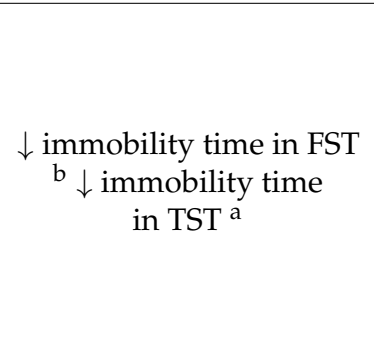 & $\begin{array}{c}\downarrow \text { microglia } \mathrm{w} / \text { activated } \\
\text { morphologies } \downarrow \text { Ib-A1 } \\
\text { immunoreactivity } \mathrm{b} \uparrow \\
\text { BrdU+ cells } \mathrm{b} \uparrow \mathrm{DCX}+ \\
\text { neurons } \mathrm{b} \uparrow \text { type- } 1 \\
\text { RGL cells } \mathrm{a} \uparrow \text { symmetric } \\
\text { division of RGL cells }{ }^{\mathrm{b}} \downarrow \\
\text { hippocampal }^{\mathrm{h}} \\
\text { NF- } \mathrm{kB} \text { expression }\end{array}$ \\
\hline $\begin{array}{l}\text { Liu and colleagues, } \\
2016 \text { [28] }\end{array}$ & $\begin{array}{l}\text { CUMS-exposed male } \\
\text { Wistar rats }\end{array}$ & $\begin{array}{l}\text { Vehicle RSV CUMS + } \\
\text { vehicle CUMS + RSV CUMS } \\
+ \text { ketamine } \times 4 \text { weeks }\end{array}$ & $\begin{array}{l}\text { RSV: } 80 \text {, i.p. Ketamine: } 20 \text {, } \\
\text { i.p. Vehicle: } 1 \% \text { ethanol, i.p. }\end{array}$ & $\begin{array}{c}\uparrow \text { sucrose preference }^{\mathrm{a}} \downarrow \\
\text { immobility time in FST } \\
\uparrow \text { locomotor activity }^{\mathrm{a}}\end{array}$ & 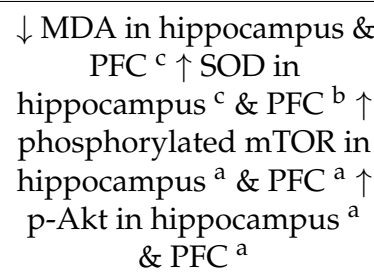 \\
\hline $\begin{array}{l}\text { López and colleagues, } \\
2014 \text { [29] }\end{array}$ & male $\mathrm{CD} 1$ mice & $\begin{array}{l}\text { vehicle (saline) DMSO 1\% } \\
\text { DMSO 10\% RSV OXO } 4 \\
\text { buproprion citalopram DES } \\
\text { imipramine moclobemide } \\
\text { nisoxetine nomifensine }\end{array}$ & $\begin{array}{l}\text { RSV: } 2.5,5,10 \text { i.p. OXO 4: } 1 \text {, } \\
\text { i.p. buproprion: } 10 \text { i.p. } \\
\text { citalopram: } 20 \text { i.p. DES: } 35 \\
\text { i.p. imipramine: } 35 \text { i.p. } \\
\text { moclobemide: } 35 \text { i.p. } \\
\text { nisoxetine: } 2.5 \text { i.p. } \\
\text { nomifensine: } 2.5 \text { i.p. }\end{array}$ & $\begin{array}{l}\downarrow \text { immobility time } \\
\quad \text { in FST a(10) }\end{array}$ & $\mathrm{N} / \mathrm{A}$ \\
\hline
\end{tabular}


Table 1. Cont.

\begin{tabular}{|c|c|c|c|c|c|}
\hline Author, Year & Animal Model & Intervention & Dosage/Route & $\begin{array}{c}\text { Behavioral Outcomes } \\
\text { w/RSV Txt }\end{array}$ & $\begin{array}{c}\text { Clinical Outcomes } \\
\text { w/RSV Txt }\end{array}$ \\
\hline $\begin{array}{c}\text { Pang and colleagues, } \\
2015 \text { [30] }\end{array}$ & $\begin{array}{l}\text { middle cerebral artery } \\
\text { occluded male } \\
\text { Sprague-Dawley rats }\end{array}$ & $\begin{array}{l}\text { sham/vehicle MCAO } \\
\text { MCAO + RES MCAO + } \\
\text { imipramine } \times 7 \text { days } \\
\text { pre-surgery; tested either } \\
\text { day } 8 \text { or days } 20-21\end{array}$ & $\begin{array}{l}\text { RSV: } 10,20,40 \text {, oral } \\
\text { imipramine: } 10 \text { i.p. }\end{array}$ & $\begin{array}{l}\uparrow \text { sucrose preference } \\
\text { a,b }(20 / 40) \downarrow \text { immobility } \\
\text { time in FST a,c }(20 / 40) \\
\sim \text { locomotor activity }\end{array}$ & $\begin{array}{c}\uparrow \text { hippocampal BDNF }{ }^{\mathrm{a}} \uparrow \\
\text { hippocampal } \beta \text {-actin } \mathrm{a} \downarrow \\
\text { adrenal gland index } \mathrm{b}(40) \\
\downarrow \text { CRF expression in FC, } \\
\text { hippocampus, and } \\
\text { hypothalamus b,c (20/40) } \downarrow \\
\text { glucocorticoid receptor } \\
\text { expression in FC } \mathrm{b}, \mathrm{c}(20 / 40) \text {, } \\
\text { hippocampus } \mathrm{b}, \mathrm{c}(20 / 40), \\
\text { and hypothalamus } \mathrm{a}(40) \uparrow \\
\text { BDNF expression in FC } \\
\text { a, a (20/40), hippocampus } \\
\text { b,b (20/40), and } \\
\text { hypothalamus b, } \mathrm{b}(20 / 40)\end{array}$ \\
\hline $\begin{array}{l}\text { Sakr and colleagues, } \\
2015[31]\end{array}$ & $\begin{array}{l}\text { CUMS- exposed male } \\
\text { Sprague-Dawley rats }\end{array}$ & $\begin{array}{c}\text { CUMS + watercontrol } \\
\text { CUMS + FLX water CUMS } \\
+ \text { RSV CUMS + FLX/RSV × } \\
4 \text { weeks ctrl + water ctrl + } \\
\text { FLX ctrl + RSV ctrl + } \\
\text { FLX/RSV }\end{array}$ & FLX: 10, oral RSV: 20, oral & $\begin{array}{l}\uparrow \text { sucrose preference }^{\mathrm{a} \uparrow} \\
\text { immobility time in FST }\end{array}$ & $\begin{array}{c}\downarrow \text { serum CORT }{ }^{\mathrm{a}} \downarrow \text { 5-HT in } \\
\text { cerebral cortex and } \\
\text { hippocampus }^{\mathrm{a}} \uparrow \text { serum } \\
\text { testosterone }^{\mathrm{a}} \uparrow \text { testicular } \\
\text { SOD }^{\mathrm{a}} \uparrow \text { testicular CAT }^{\mathrm{a}} \uparrow \\
\text { testicular GSH } \\
\text { testicular MDA }^{\mathrm{a}}\end{array}$ \\
\hline $\begin{array}{l}\text { Wang and colleagues, } \\
2013 \text { [32] }\end{array}$ & male Kunming mice & $\begin{array}{l}\text { Vehicle RSV FLX } \times 21 \text { days; } \\
\text { tests followed }\end{array}$ & $\begin{array}{l}\text { RSV: } 20,40,80 \text {, i.p. FLX: } 10 \text {, } \\
\text { i.p. Vehicle: } 1 \% \text { ethanol, i.p., } \\
0.9 \% \mathrm{NaCl} \text {, i.p. }\end{array}$ & $\begin{array}{c}\downarrow \text { immobility time in FST } \\
\text { a,b,c }(20 / 40 / 80) \\
\downarrow \text { immobility } \\
\text { time in TST }{ }^{a}, \mathrm{c}, \mathrm{c}(20 / 40 / 80) \\
\sim \text { locomotor activity } \\
\mathrm{d}\end{array}$ & $\begin{array}{c}\downarrow \text { serum CORT } \mathrm{b}(80) \uparrow \mathrm{PFC} \\
\text { BDNF c,c,c (20/40/80) } \\
\text { hippocampal BDNF } \\
\mathrm{c,c}(40 / 80) \uparrow \mathrm{pERK} 1 / 2 \text { in } \\
\text { PFC a,a,c \& hippocampus } \\
\text { a,b,c }(20 / 40 / 80)\end{array}$ \\
\hline
\end{tabular}


Table 1. Cont.

\begin{tabular}{|c|c|c|c|c|c|}
\hline Author, Year & Animal Model & Intervention & Dosage/Route & $\begin{array}{c}\text { Behavioral Outcomes } \\
\text { w/RSV Txt }\end{array}$ & $\begin{array}{c}\text { Clinical Outcomes } \\
\text { w/RSV Txt }\end{array}$ \\
\hline $\begin{array}{l}\text { Wang and colleagues, } \\
2016 \text { [33] }\end{array}$ & $\begin{array}{l}\text { CRS-exposed male } \\
\text { Wistar rats }\end{array}$ & $\begin{array}{l}\text { RSV FLX CRS exposed } 30 \\
\text { min after injection } \\
\times 21 \text { days }\end{array}$ & RSV: 80, i.p. FLX: 10, i.p. & $\begin{array}{c}\uparrow \text { sucrose preference }^{\mathrm{a}} \downarrow \\
\text { immobility time in FST } \\
\sim \text { locomotor activity } \\
{ }^{\mathrm{a}}\end{array}$ & 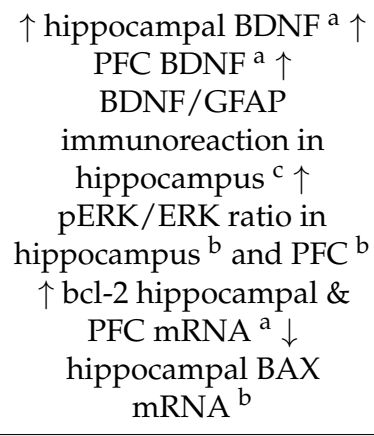 \\
\hline $\begin{array}{c}\text { Wang and colleagues, } \\
2018 \text { [34] }\end{array}$ & $\begin{array}{l}\text { ouabain- exposed female } \\
\text { J20 mice }\end{array}$ & $\begin{array}{c}\text { ouabain + PBS }(\text { control) } \\
\text { ouabain + RSV } \times 10 \text { weeks }\end{array}$ & RSV: 10 , oral & $\begin{array}{c}\uparrow \text { distance moved }{ }^{\mathrm{a}} \uparrow \text { path } \\
\text { efficiency }{ }^{\mathrm{a}} \downarrow \text { time to } \\
\text { recognize novel object }^{\mathrm{a}} \downarrow \\
\text { Rankin score }^{\mathrm{a}}\end{array}$ & 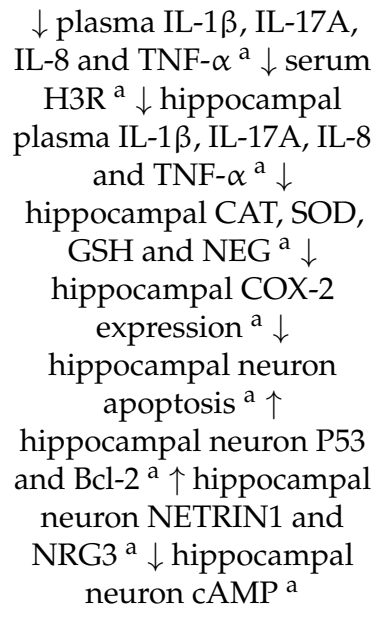 \\
\hline
\end{tabular}


Table 1. Cont.

\begin{tabular}{|c|c|c|c|c|c|}
\hline Author, Year & Animal Model & Intervention & Dosage/Route & $\begin{array}{c}\text { Behavioral Outcomes } \\
\text { w/RSV Txt }\end{array}$ & $\begin{array}{l}\text { Clinical Outcomes } \\
\text { w/RSV Txt }\end{array}$ \\
\hline $\begin{array}{l}\text { Xu and colleagues, } \\
2010[7]\end{array}$ & male ICR mice & $\begin{array}{l}\text { RSV Moclobemide (MAOI) } \\
\text { Imipramine (TCA) } \\
\text { Fluoxetine (SSRI) Treated } \\
\text { w/PCPA or vehicle prior to } \\
\text { FST \& TST; treated } \\
\text { w/apomorphine or vehicle } \\
\text { after RSV Txt; behavioral } \\
\text { tests } 30 \text { min post-RSV }\end{array}$ & $\begin{array}{l}\text { RSV: } 20,40,80 \text {, i.g. } \\
\text { Moclobemide: } 20 \text {, i.p. } \\
\text { Imipramine: } 20 \text {, i.p. } \\
\text { Fluoxetine: } 10 \text {, i.p. PCPA: } \\
\text { 300, i.p. Apomorphine: } 16 \text {, } \\
\text { s.c. Vehicle }\end{array}$ & $\begin{array}{c}\downarrow \text { immobility time in FST } \\
\text { a,b,c }(20 / 40 / 80) \downarrow \text { immobility } \\
\text { time in TST a,a,a (20/40/80) } \\
\sim \text { locomotor activity } \mathrm{d}\end{array}$ & 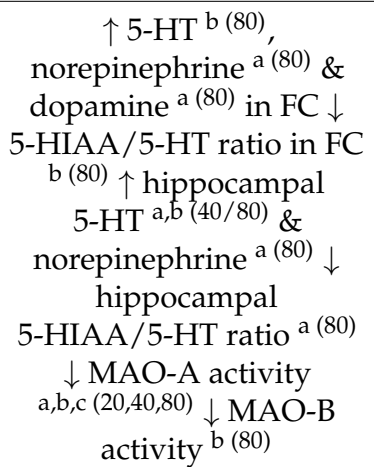 \\
\hline
\end{tabular}

${ }^{\mathrm{a}} p<0.05,{ }^{\mathrm{b}} p<0.01,{ }^{\mathrm{c}} p<0.001,{ }^{\mathrm{d}} p>0.05 \sim$ No change, ${ }^{*} \mathrm{ug} / \mathrm{kg} / \mathrm{d}$ (All others mg/kg/day). 5-HIAA, 5-hydroxyindoleacetic acid; 5-HT, serotonin; ATP, adenosine triphosphate; bcl-2,ind B-cell lymphoma 2; BAX, bcl-2-like protein 4; BDNF, brain-derived neurotrophic factor; BrdU, bromodeoxyuridine; CORT, corticosterone; CRH, corticotrophin-releasing hormone; CRS, chronic restraint stress; CUMS, chronic unpredictable mild stress; DES, desipramine; DCX, doublecortin; DMSO, dimethyl sulfoxide; FC, frontal cortex; FLX, fluoxetine; FST, forced swimming test; GFAP, glial fibrillary acidic protein; GSH, glutathione; GSK, glycogen synthase kinase; i.c.v., intracerebroventricular; i.g., intragastric; i.p., intraperitoneal; IL, interleukin; LPS, lipopolysaccharide; LT4, levothyroxine; MAO-A, monoamine oxidase A; MAO-B, monoamine oxidase B; MAOI, monoamine oxidase inhibitor; MCAO, middle cerebral artery occlusion; MDA, malondialdehyde; NEG, neuroglobin; mTOR, mammalian target of rapamycin; OXO 4, 5-methoxyoxoisoaporphine; $\mathrm{p} \beta$-catenin, phosphorylated $\beta$-catenin; PCPA, parachlorophenylalanine; $\mathrm{pCREB}$, phosphorylated $\mathrm{cAMP}$ response element binding protein; $\mathrm{PFC}$, prefrontal cortex; pGSK, phosphorylated glycogen synthase kinase; $\mathrm{pNF}-\mathrm{kB}$, phosphorylated NF-kB; RGL, radial-glia-like cell; RSV, resveratrol; s.c., subcutaneous; $\mathrm{SCH}$, subclinical hypothyroidism; SOD, superoxide dismutase; SSR, selective serotonin reuptake inhibitor; TCA, tricyclic antidepressant; TNF, tumor necrosis factor; TRH, thyrotropin-releasing hormone; TSH, thyroid-stimulating hormone; TST, tail suspension test; Txt, treatment. 


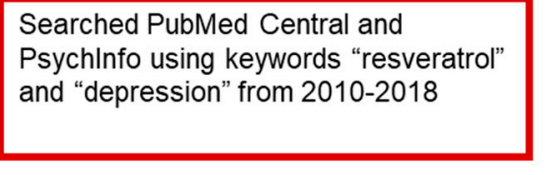

Yielded 1859 articles from PubMed Central and 23 articles from PsychInfo

340 article titles met preliminary criteria based on title

16 articles met criteria based on abstract

10 articles meet criteria

Total 22 articles for final review
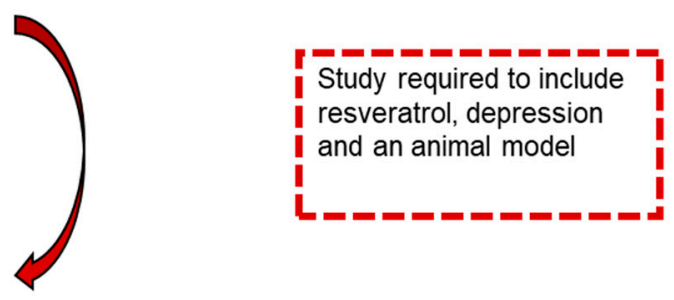

Study must meet following criteria:

I animal model of depression,

- compared to control and/or

- pharmaceutical antidepressant,

standardized protocol used for

assessing depressive behaviors,

physiological mechanisms explored 1

1

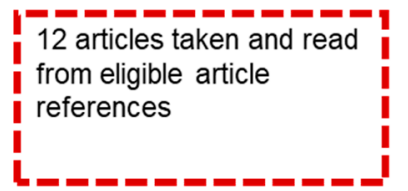

Figure 1. Process of article selection for final review.

\section{Results}

\subsection{Resveratrol's Effect on Depressive Behaviors}

Several different tests were utilized to investigate the effects of resveratrol on depressive behaviors, including the forced swimming test (FST), tail suspension test (TST), sucrose preference test, and open field test (OFT). The FST and TST assess helplessness or behavioral despair, with higher immobility time indicating greater depressive behaviors [35]. Decreased sucrose preference indicates anhedonia, a common symptom of depression defined as the loss of the ability to feel pleasure [18]. The OFT measures locomotor activity, with reduced locomotor activity indicating anxiety-like behaviors associated with depression [28]. Other studies used the OFT as a measure of resveratrol's specificity, as psychostimulants similarly decrease immobility time in the FST and TST, but cause an increase in locomotor activity [7,35,36].

In animal models of depression, resveratrol increases sucrose consumption in a dose-dependent manner, demonstrating resveratrol's ability to counteract the reduction in reward-seeking behavior that tends to occur with depression [16,18,21,22,26,28]. Animals also exhibit decreased immobility time in the FST and TST, with resveratrol treatment ranging from $15-80 \mathrm{mg} / \mathrm{kg} /$ day $[5,6,16,18,21,22,24,26,28,32]$. Moreover, resveratrol has been shown to reduce depressive behaviors in rodents to a similar degree as the antidepressants fluoxetine, desipramine, and ketamine [7,16,18,21,26,28,32]. Several studies reveal that resveratrol has no effect on locomotor activity in the OFT, indicating its specificity $[6,7,22,32,33]$, while others show a reversal of decreased locomotor activity, demonstrating resveratrol's ability to reduce anxiety-like behaviors associated with depression [16,28]. 


\subsection{HPA Axis Regulation}

The HPA axis is a major endocrine system in the body that regulates how individuals adapt and behave in the face of stress. When a stressor presents, the paraventricular nucleus (PVN) of the hypothalamus releases corticotropin-releasing hormone $(\mathrm{CRH})$, which stimulates the release of adrenocorticotropic hormone (ACTH) from the anterior pituitary. ACTH enters the bloodstream and causes the release of glucocorticoids (cortisol in humans and corticosterone in animals) from the adrenal glands [37].

Studies show that serum and plasma cortisol is higher in individuals suffering from major depression [38-40]. Resveratrol attenuates this increase in serum and plasma corticosterone in several animal models of depression $[16,18,21,26,32]$. In one study, mice receiving corticosterone had significantly higher serum corticosterone levels than control animals, but resveratrol $(80 \mathrm{mg} / \mathrm{kg} /$ day) reversed this effect similarly to fluoxetine [18]. Wang and colleagues also found that mice induced with stress via the FST and TST had lower serum corticosterone after 21 days of either resveratrol or fluoxetine treatment than vehicle mice [32].

In a rat model of subclinical hypothyroidism-induced depression, resveratrol not only reduced plasma corticosterone levels and depressive behaviors, but also hypothalamic CRH mRNA expression and levels of thyrotropin-releasing hormone (TRH) and thyroid stimulating hormone (TSH) [16]. These results support the direct effect of resveratrol on hypothalamic activity. In contrast, others have recognized a decrease in serum corticosterone but no change in CRH mRNA expression with resveratrol treatment [21]. Together, these results illustrate the beneficial effects of resveratrol on regulating the HPA axis in animal models of depression.

\subsection{Decreased Inflammation}

Chronic inflammation has been associated with both psychological stress and the pathology of depression [40]. Medically ill patients with increased inflammatory cytokines have higher rates of depression, and even in the absence of medical illness, individuals with depression exhibit increased pro-inflammatory cytokines [41]. Pathogens or stress trigger a signaling cascade which activates transcription factors such as nuclear factor- $\mathrm{KB}(\mathrm{NF}-\mathrm{kB})$, which in turn increase the expression of pro-inflammatory genes [40].

Pro-inflammatory cytokines, including interleukin-1 (IL-1), interleukin-6 (IL-6), and tumor necrosis factor- $\alpha$ (TNF- $\alpha)$, play a key role in the immune and inflammatory response. While pro-inflammatory cytokines work to mitigate infection in the short term, continuous inflammation resulting from prolonged activation can lead to poor health outcomes and depression. In fact, one way that pro-inflammatory factors attempt to protect the organism is by promoting social withdrawal, a behavior displayed by depressed patients [40]. Resveratrol is able to downregulate NF- $\mathrm{kB}$ expression in the hippocampus [5,21] and prefrontal cortex [22] in mice treated with lipopolysaccharide (LPS). In addition, resveratrol supplementation reduces levels of pro-inflammatory cytokines (IL-1 $\beta$, IL-2, IL-4, IL-6, TNF- $\alpha$ ) in animal models of depression [20,22].

Resveratrol is able to reduce microglial activation and Iba1 labeling of microglia in the hippocampus, establishing its anti-inflammatory effect [5,24]. Microglia are immune cells that reside in the brain. Overactivation of microglia occurs when neurons are damaged and is associated with several neurodegenerative disorders including depression [42].

\subsection{Decreased Oxidative Stress}

Depression is characterized by increased oxidative stress, as indicated by higher levels of malondialdehyde (MDA) and 8-hydroxy-2-deoxyguanosine (8-OHdG). Some studies have also shown decreased antioxidant status, although these results are less consistent [43]. Although resveratrol's direct antioxidant effects are modest, this polyphenol significantly reduces oxidative stress through its effects on gene expression, which include upregulation of antioxidant enzyme production and 
downregulation of reactive oxygen species (ROS) production [44]. Two studies in male rats exposed to chronic unpredictable mild stress (CUMS) showed reductions in oxidative stress following resveratrol treatment, which also reduced depression-like symptoms. Serum MDA was significantly reduced by $15 \mathrm{mg} / \mathrm{kg} /$ day of resveratrol, while a higher dosage $(80 \mathrm{mg} / \mathrm{kg} /$ day) reduced MDA and increased superoxide dismutase (SOD) in the prefrontal cortex and hippocampus $[21,28]$.

\subsection{Decreased Amyloid Beta Cytotoxicity}

Amyloid beta $(A \beta)$, the primary component of plaques found in the brains of Alzheimer's disease patients, may also promote depression by impairing function of the serotonin neurotransmitter system [45]. In rat and human cell cultures, resveratrol has demonstrated the ability to reduce $A \beta$ levels and to attenuate $A \beta$-induced cytotoxicity and cell death [46-49]. Cells exposed to $A \beta$ exhibited increased NF-KB activity, but pretreatment with resveratrol inhibited this effect [48]. These results suggest that resveratrol's antidepressant effects may occur partly through a reduction in neural $\mathrm{A} \beta$ levels.

\subsection{Increased Neurogenesis}

\subsubsection{Brain-Derived Neurotrophic Factor (BDNF)}

Brain-Derived Neurotrophic Factor (BDNF) is imperative for neuroprotection due to its roles in neuronal plasticity and survival, synaptic transmission, and neurotransmitter synthesis [50]. Chronic stress and glucocorticoids decrease BDNF [51,52], while it is believed that antidepressants exert their effects in part by increasing BDNF levels [53]. In rodents, resveratrol increases BDNF levels in various brain regions, including the hippocampus [6,18,22,26,32], prefrontal cortex [6,26,32], and amygdala [26]. Notably, when corticosterone was administered to mice, levels of BDNF decreased in the hippocampus, but resveratrol attenuated this effect similarly to fluoxetine [18]. Hurley and colleagues showed that BDNF was increased in the hippocampus by both acute resveratrol treatment, and chronic administration over a seven-day period [6].

\subsection{2. cAMP Response Element Binding Protein}

Cyclic AMP response element-binding protein (CREB) is a transcription factor associated with depression [54]. Low levels of CREB activity are implicated in depression [54], while chronic administration of antidepressants increases CREB mRNA expression in various brain regions of rodents $[55,56]$. Phosphorylated CREB (pCREB) binds to a receptor on the promoter region of the BDNF gene, enhancing its transcription [22,57]. Resveratrol increased pCREB and BDNF in the hippocampus, prefrontal cortex, and amygdala of mice exposed to LPS [22] and rats exposed to CUMS [26]. Thus, resveratrol may act similarly to classical antidepressants by upregulating CREB activity, thereby increasing BDNF expression.

\subsubsection{Extracellular Regulated Kinase Pathway}

Extracellular regulated kinase (ERK) signaling is involved in the survival and resilience of neurons [24]. In both humans and rodents, studies show that defects in the ERK signaling cascade are associated with depression [58,59]. In rats exposed to CUMS, antidepressants increase phosphorylation of ERK (pERK) [60] and hippocampal BDNF expression [61]. Resveratrol has also been shown to increase $\mathrm{pERK}$ in both the hippocampus [26,32,33] and prefrontal cortex [32,33] of rodents. Studies demonstrate that BDNF exerts antidepressant activity by upregulating the ERK pathway. Therefore, resveratrol may alleviate depressive symptoms both by increasing BDNF and by upregulating the ERK signaling cascade $[26,32,33]$. 


\subsubsection{Neural Stem Cells}

Neural stem cells reside in the subgranular zone of the dentate gyrus. Radial glia-like (RGL) cells have a bipolar structure and function as the main progenitor cells for adult hippocampal neurogenesis [5]. In mice administered LPS, resveratrol increased the number of RGL cells by increasing symmetric division [5]. Not only did resveratrol treatment increase the number of newly born cells and neurons in the hippocampus, these neurons lasted for at least two weeks, demonstrating the long-term effects of resveratrol treatment $[5,24]$.

\subsubsection{Mammalian Target of Rapamycin (mTOR) Pathway}

Mammalian target of rapamycin (mTOR) is a serine/threonine protein kinase involved in cell proliferation, survival, and protein synthesis [62]. It has been elucidated that phosphorylation of the mTOR signaling pathway is severely decreased in patients with major depression, while ketamine, an $N$-methyl-D-aspartate (NMDA) antagonist, has been shown to increase mTOR activity and relieve depression [63]. Following phosphorylation, Akt/protein kinase B (Akt) activates the mTOR signaling pathway [28]. Resveratrol is comparable to ketamine in reducing depressive symptoms and increasing Akt and mTOR levels in the hippocampus and prefrontal cortex of rats [28]. Therefore, resveratrol may ameliorate depressive symptoms via phosphorylation of Akt and subsequent activation of the mTOR pathway.

\subsubsection{Canonical Pathway of Wnt- $\beta$-Catenin}

Wnt- $\beta$-Catenin signaling plays a significant role in regulating hippocampal neurogenesis $[64,65]$. Dysregulation of this pathway is associated with several neuropsychiatric disorders including depression $[65,66]$. In addition, GSK-3 $\beta$, a kinase involved in Wnt signaling, is used as a marker in neuropsychiatric disorders and is targeted by mood-stabilizing drugs such as lithium for bipolar disorder $[65,67]$.

Rats with subclinical hypothyroidism-associated depression exhibited increased levels of GSK-3 $\beta$ and phosphorylated $\beta$-catenin, while c-myc and cyclin D1 were decreased. Resveratrol attenuated these effects by decreasing GSK-3 $\beta$ and phosphorylated $\beta$-catenin while increasing expression of the Wnt target genes c-myc and cyclin D1. These effects were accompanied by increased sucrose preference and decreased immobility time in the FST, indicating a reduction in behavioral symptoms of depression [16].

\subsection{Serotonin, Norepinephrine, \& Dopamine}

Current pharmacotherapies for depression act on monoamine neurotransmitters, including serotonin and norepinephrine. SSRIs and SNRIs prevent reuptake of serotonin or norepinephrine, while MAOIs inhibit monoamine oxidase (MAO), the enzyme responsible for degrading serotonin and norepinephrine [68]. Dopamine, which is responsible for reward and motivation, has also been implicated in depression, as modulating dopamine-producing neurons can either induce or mitigate depressive behaviors such as anhedonia [69]. In rodents, resveratrol has been shown to increase serotonin in the frontal cortex, hippocampus, and striatum; norepinephrine in the frontal cortex and hippocampus; and dopamine in the frontal cortex and striatum [7,70]. In mice, resveratrol also decreased levels of the enzymes MAO A and B, which reduce neurotransmitter levels through oxidative deamination $[7,23]$. Treatment with resveratrol decreased depressive behaviors-however, the effects of resveratrol diminished in the absence of serotonin. Taken together, these results demonstrate that resveratrol may reduce depressive behaviors in mice via the serotonergic and noradrenergic systems [7].

Figure 2 shows the major proposed mechanisms by which resveratrol exerts antidepressant effects. These mechanisms include modulation of the hypothalamic-pituitary-adrenal (HPA) axis, reduction of 
inflammation and oxidative stress, increased neurogenesis, altered monoamine levels, and reduction in amyloid beta plaques.

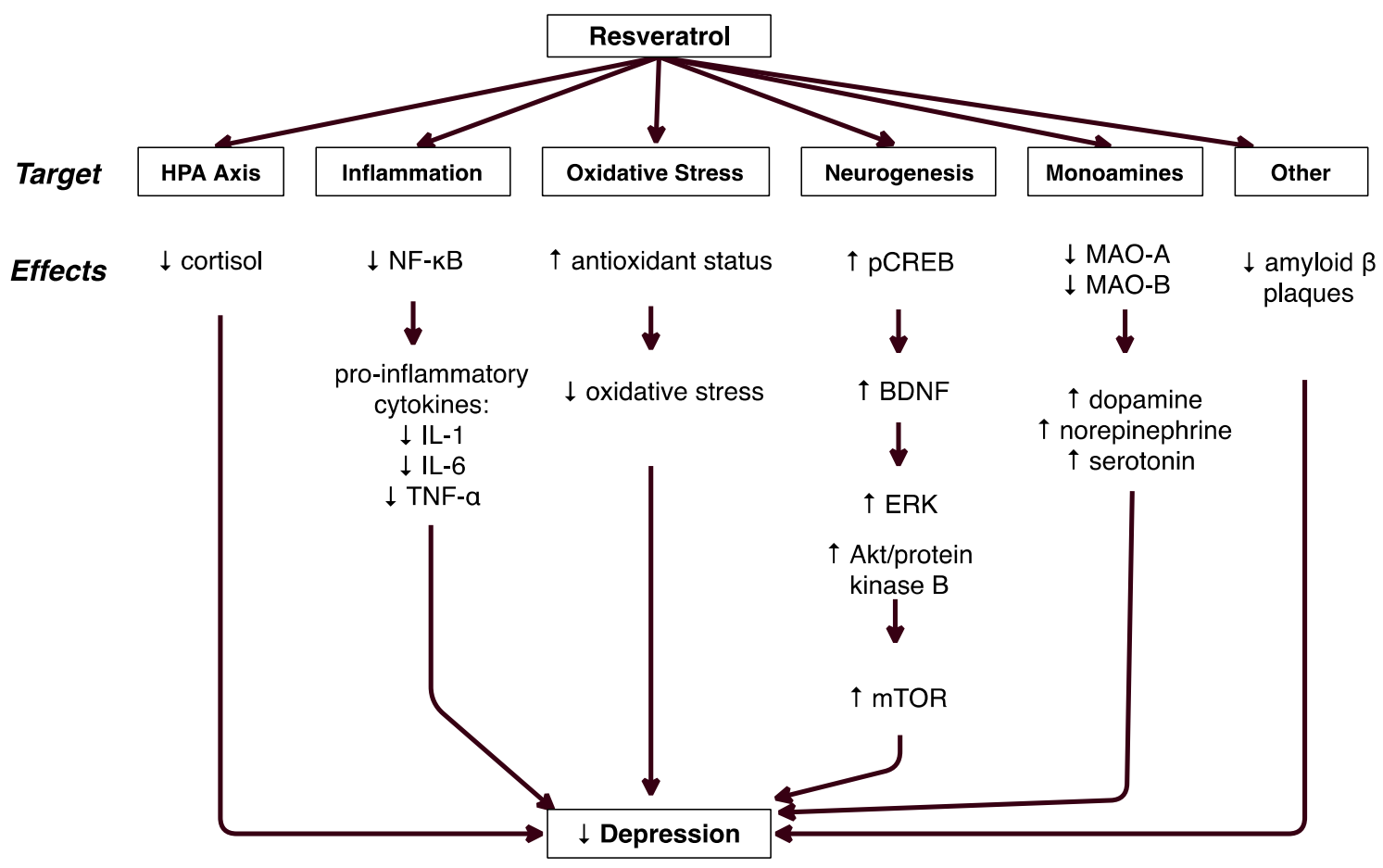

Figure 2. Proposed Mechanisms of Antidepressant Effects of Resveratrol.

\section{Discussion}

Based on the current literature, resveratrol is a promising novel therapy for the treatment of depression. This natural polyphenol decreases behavioral symptoms of depression and improves biological parameters associated with depression in animal models $[5-7,16,18,20-22,24,26,28,32,33]$. The effects of resveratrol treatment are similar to those of classical antidepressants $[7,16,18,19,21,26,32]$, validating its potential use as a therapeutic agent. For many, the side effects of antidepressants are deleterious [8]. This has created an urgent need for new treatments that can improve the symptoms of depression without compromising wellbeing.

Importantly, resveratrol reduced depressive symptoms in all studies reviewed regardless of the type of stress induced. Models used in the studies included corticosterone injection [18], social stress exposure [20], CUMS [21,26,28], LPS injection [5,22], subclinical hypothyroidism [16], chronic restraint stress (CRS) [33], and stress induced by tests of behavioral despair $[6,7,24,32]$. The causes of depression are multifactorial, and it is evident that many brain regions and neural pathways are involved [6]. Resveratrol was found to decrease depressive symptoms in rodents by regulating the HPA axis, decreasing inflammation, and increasing neurogenesis.

The HPA axis is a hormonal stress response system. In the healthy individual, the HPA axis is regulated by negative feedback mechanisms that prevent cortisol overproduction [28]. In depressed individuals, the HPA axis is dysregulated, causing either chronically high cortisol levels or a flattened cortisol curve referred to as the diurnal slope [38-40,71]. Cortisol must effectively bind to its glucocorticoid receptor on the PVN and the anterior pituitary for inhibition to occur. It is speculated that improper binding of cortisol to its receptor during negative feedback causes excessive production of cortisol or an abnormal cortisol curve [37,72,73].

In one study, healthy premenopausal women or those diagnosed with major depression were administered dexamethasone, which binds to the glucocorticoid receptor and suppresses cortisol production. Although cortisol production was reduced in all participants, those diagnosed with major 
depression showed less suppression than non-depressed controls. In addition, depressed subjects had flatter diurnal cortisol curves than non-depressed subjects [72]. These results illustrate that HPA axis dysfunction is a strong indicator of depression.

As demonstrated by the present review, resveratrol effectively reduced corticosterone in several animal models of depression $[16,18,21,26,32]$. These results coincide with studies of classical antidepressants that exhibit decreased stress response and corticosterone levels in aquatic animals exposed to fluoxetine and diazepam [74]. Resveratrol decreased corticosterone levels similarly to SSRIs and simultaneously improved depressive behaviors. Thus, resveratrol may be considered a regulator of the HPA axis in its ability to reduce corticosterone in animal models of depression.

Much research has focused upon the association between inflammation and depression, and results show that regardless of a comorbid medical illness, inflammation is often present in depressed patients 41]. While it is unclear whether inflammation causes depression or the reverse, it is well known that pro-inflammatory cytokines have effects that could contribute to depressive symptoms [75]. For example, research shows that pro-inflammatory cytokines activate the HPA axis by stimulating $\mathrm{CRH}$ release by the hypothalamus and ACTH release by the pituitary, thereby increasing cortisol production [76]. Pro-inflammatory cytokines can also decrease serotonin synthesis in the brain and play a role in neuronal development and plasticity. Chronic stress activates microglia, which secrete pro-inflammatory cytokines that create inflammation and inhibit neurogenesis [75]. Depressed individuals exhibit upregulation of NF- $\mathrm{KB}$, which is also involved in the release of pro-inflammatory cytokines. In vitro, resveratrol inhibited the activation of NF- $k B$ by IL-1 $\beta[5,77]$. The fact that resveratrol reduced both NF- $\mathrm{KB}$ expression and pro-inflammatory cytokines in animal models of depression suggests that resveratrol may attenuate the effects of inflammation on depression by downregulating the NF- $\mathrm{kB}$ signaling pathway.

Growing evidence suggests that oxidative stress is involved in the pathogenesis of depression. A recent meta-analysis of 23 observational studies found a significant association between depression and oxidative stress, and post-mortem studies have found indications of oxidative stress in the prefrontal cortex of patients with major depression [78,79]. MDA levels are positively associated with depression, particularly in patients who experience recurring episodes [34]. Another oxidative stress biomarker, 8-OHdG, is typically increased in depressed patients compared to healthy controls and correlates with the severity of depression [43]. Some studies show decreased levels of the SOD and glutathione, a finding consistent with the hypothesis that excessive ROS have overwhelmed the body's antioxidant defenses. However, other studies have shown a positive relationship between antioxidant levels and depressive symptoms, and more research is needed to elucidate this relationship.

In addition to damaging cells, ROS can activate stress-responsive kinases including ERK, Jun $\mathrm{N}$-terminal kinase (JNK), and p38, which in turn increase inflammation by activating NF- $\mathrm{KB}$ [80]. Resveratrol exerts antioxidant effects by scavenging free radicals, and through its effects on redox-related gene expression [44]. Although few of the studies in this review examined oxidative stress and antioxidant markers, two studies in CUMS-exposed male rats did show reductions in MDA following resveratrol treatment. In a study by Ge et al., $15 \mathrm{mg} / \mathrm{kg} /$ day of resveratrol significantly decreased MDA in serum [21]. Subsequently, Liu et al. found that $80 \mathrm{mg} / \mathrm{kg} /$ day of resveratrol reduced MDA and increased SOD in the prefrontal cortex and hippocampus [28]. Both studies also showed that resveratrol reduced depression-like symptoms, as indicated by sucrose preference, FST, and TST.

Depression affects up to $90 \%$ of Alzheimer's disease (AD) patients and is considered a major risk factor for the disease [81]. Depression frequently precedes cognitive impairment in AD, possibly pointing to a common pathology underlying these psychiatric disorders [45]. One of the characteristic features of $\mathrm{AD}$ is the accumulation of plaques, which are composed primarily of the peptide amyloid beta $(A \beta)$. Rather than simply being a marker of disease activity, $A \beta$ appears to contribute directly to disease progression. For example, injected $A \beta$ has been shown to impair memory and induce depressive-like behavior in mice [82]. A $\beta$ appears to affect several of the mechanisms explored in 
this review. Like depression, AD is characterized by chronic inflammation and increased blood levels of proinflammatory cytokines $[41,83]$. In mice, intracerebroventricular infusion of $A \beta$ was shown to increase mRNA expression and hippocampal levels of TNF- $\alpha$ [81]. Higher levels of TNF- $\alpha$ are associated with increased depressive-like behavior, as indicated by FST and SPT. However, when the mice were administered infliximab, an anti-TNF- $\alpha$ antibody, depression symptoms were reduced [81].

Increased production of proinflammatory cytokines is associated with altered serotonin (5-HT) metabolism. In mice, A $\beta$ significantly decreased brain 5-HT levels, but pretreatment with 5-HT prevented $A \beta$-induced microglial activation and TNF- $\alpha$ production [81]. However, mice deficient in toll-like receptor 4 (TLR4 ${ }^{-/-}$) did not exhibit reduced 5-HT levels or increased depressive-like behavior. TLR4 levels were also elevated in AD patients and transgenic mouse models of AD. These results indicate that TLR4 may play a key role in modulating the depression-promoting effects of $A \beta$ in mice, possibly by upregulating NF-kB, which increases production of inflammatory cytokines.

Another link between AD and depression is increased oxidative stress caused by elevated levels of ROS [48]. A $\beta$ increases oxidative stress, and has been shown to induce apoptosis by generating hydrogen peroxide [48]. A $\beta$ has also been reported to modulate the HPA axis. In a rat model of AD, $\mathrm{A} \beta$ increased norepinephrine in the prefrontal cortex and hippocampus while decreasing production in the amygdala [84]. Interestingly, corticosterone is typically elevated in animal models of depression; however, plasma corticosterone was decreased in A $\beta$-treated rats [84]. Resveratrol has been shown to significantly reduce secreted and intracellular levels of amyloid beta [46-49]. In addition, resveratrol attenuated $\mathrm{A} \beta$-induced cytotoxicity and apoptosis [46-48]. These findings suggest that resveratrol may reduce the neurotoxicity of $A \beta$ through several mechanisms, thus contributing to the antidepressant effects of this polyphenol.

As reported, resveratrol increased BDNF expression and decreased behavioral symptoms in several animal models of depression $[6,18,22,32,33]$. Previous research contends that levels of BDNF are lower in depressed individuals and that antidepressants raise levels of BDNF. There is strong evidence supporting the existence of a relationship between depression and BDNF expression, but exactly how antidepressant medications and resveratrol are able to manipulate this relationship is still being researched. It has been postulated that low levels of BDNF are partly caused by high glucocorticoid production. It is worth noting that some studies demonstrated a decrease in serum corticosterone alongside increased BDNF following resveratrol treatment [18,26,32].

Additionally, it is speculated that BDNF is regulated by both CREB expression and the ERK signaling pathway [85]. Based on the evidence that low levels of phosphorylated CREB (pCREB) are implicated in depression, and that this protein enhances BDNF transcription, it is reasonable to consider that increasing PCREB would decrease depressive symptoms. As discussed, resveratrol upregulated pCREB and BDNF while decreasing depressive behaviors, so it is conceivable that resveratrol exerts its effects via this mechanism [22,57]. However, another study found that resveratrol lowered pCREB and BDNF and subsequently reduced the proliferation of neural progenitor cells in the hippocampus of healthy mice, so this mechanism remains unclear [86]. Likewise, deficiencies in ERK signaling are associated with depression, while antidepressants have been shown to upregulate both pERK and BDNF $[58,60]$. Since resveratrol had comparable effects to standard antidepressants in regulating ERK signaling, increasing BDNF, and decreasing depressive behaviors, we can conceptualize that this may be another method through which resveratrol alleviates depressive behaviors in animal models.

While the majority of studies focused upon resveratrol's effects on the HPA axis, inflammation, and BDNF expression, a few studies explored different methods by which resveratrol may reduce depressive symptoms in animals. These included resveratrol's effects on neural stem cells [5,24], the Wnt- $\beta$-catenin pathway [16], mTOR signaling [28], and monoamine synthesis [7].

Studies show that reduced neurogenesis is associated with mental illness and stress, and that inflammation inhibits neurogenesis. Antidepressants increase the proliferation, maturation, and survival of neurons in the hippocampus [87]. In congruence with these findings, resveratrol increased the symmetric division of RGLs, which contributes to neuronal proliferation [5]. 
Additionally, depression is associated with abnormalities in Wnt signaling, an essential pathway for neurogenesis [65]. Resveratrol increased neurogenesis by upregulating the Wnt signaling pathway. Resveratrol also increased mTOR signaling, which similarly promotes increased neurogenesis [62].

Resveratrol increased levels of 5-HT, norepinephrine, and dopamine in various brain regions associated with depression, which coincides with the monoamine hypothesis [88]. Depression is associated with low levels of dopamine, and irregularities in dopaminergic neurons that play a large role in reward and motivation may be responsible for the anhedonia exhibited by depressed patients [89]. Based on the large body of research that has implicated these monoamines in depression, resveratrol may decrease depressive behaviors in animals by increasing neurotransmitter levels.

In 12 animal studies, resveratrol was compared to an antidepressant drug as an active control (Table 2). Nine studies compared resveratrol or a combination of resveratrol and piperine to the SSRI fluoxetine. The TCA imipramine was employed in four studies $[7,23,29,30]$ and desipramine in two studies [26,29]. Other drugs administered included the citalopram (SSRI) [29], moclobemide (MAOI) [7,82], nisoxetine (norepinephrine reuptake inhibitor) [29], buproprion and nomifensine (norepinephrine-dopamine reuptake inhibitor) [29], and ketamine (NMDA receptor antagonist) [28]. All studies administered only a single dosage of the pharmaceutical agent, but several dosages of resveratrol were typically given in order to evaluate dose-ranging effects. In general, resveratrol and the drugs were similarly effective with regard to depression-like behavior as indicated by sucrose preference test, FST, and TST. Resveratrol also had similar biochemical effects as the antidepressants, such as lower corticosterone [7,18,21,25,31,32] and higher 5-HT levels [17,23]. The majority of studies showed that resveratrol was most effective at $80 \mathrm{mg} / \mathrm{kg} /$ day. The Human Equivalent Dose (HED) of $80 \mathrm{mg} / \mathrm{kg} /$ day in rats is $12.9 \mathrm{mg} / \mathrm{kg} /$ day. Therefore, a $60 \mathrm{~kg}$ individual would require $775 \mathrm{mg}$ of resveratrol per day to achieve similar results [90]. Based on these calculations, an effective dose of resveratrol would be more plausibly obtained through supplementation than through food or beverages.

There are limitations of this review that make it difficult to accurately compare results. Firstly, the different methods used to induce depression or stress in animal models may affect the outcomes. Secondly, some studies took physical measurements directly after injection of resveratrol, while others waited for a longer period. Thirdly, some studies examined the acute effects of resveratrol, while others looked at chronic effects. However, most studies did conduct the trials over a period of at least three weeks. Fourthly, the dose of resveratrol ranged from $10 \mathrm{mg} / \mathrm{kg} /$ day to $80 \mathrm{mg} / \mathrm{kg} / \mathrm{day}$. Although this variation in dosage permitted researchers to evaluate dose-dependent effects, it made direct comparison of the results more difficult. Fifth, there are not yet enough published studies on the subject to determine the overlying mechanisms with a high degree of certainty. Sixth, there is a lack of studies in female subjects. Although Wang et al. found that resveratrol reduced depression-like symptoms in female mice [34], all other animal studies that met our inclusion criteria were conducted in male subjects. The reliance on male subjects reflects a broader tendency within psychiatric research, as most animal models of depression were developed using male rodents, and only later applied to females. The absence of female subjects is a cause for concern, as sex differences exist regarding both depression and the response to antidepressant treatment. These differences occur not only in humans, where they may largely be explained by social and cultural factors, but also in animal models, where they suggest the role of innate neurobiological factors [91]. Male and female rats respond differently to widely-used animal models of depression, including chronic unpredictable mild stress (CUMS), forced swim test, and lipopolysaccharide (LPS) exposure [91]. Because of sex-linked differences, the results of the published studies may not be applicable to females. Future studies of resveratrol and depression should attempt to determine whether existing results can be replicated in female animals. 
Table 2. Comparison of resveratrol with antidepressant drugs.

\begin{tabular}{|c|c|c|c|c|}
\hline Author, Year & Animal Model & Txt Duration & Dosages (mg/kg/Day) & Comparative Effectiveness of RSV \\
\hline Ahmed and colleagues, 2014 [17] & $\begin{array}{l}\text { reserpine-injected adult } \\
\text { male Wistar rats }\end{array}$ & 3 day & RSV: $15,30,60$, oral FLX: 24 , oral & $\begin{array}{l}\text { >FLX: Liver GSH }{ }^{(60)}, \text { liver MDA }{ }^{(30 / 60)}=\mathrm{FLX}^{\mathrm{FST}}(60) \\
\text { 5-HT }{ }^{(15 / 30 / 60)}, \text {, norepinephrine }^{(60)} \text {, dopamine }{ }^{(15 / 30 / 60)} \\
\quad \text { brain MDA }{ }^{(60)} \\
\text { < FLX: OFT }\end{array}$ \\
\hline Ali and colleagues, 2015 [18] & $\begin{array}{l}\text { CORT-injected male Swiss } \\
\text { albino mice }\end{array}$ & 21 days & RSV: 80 , oral FLX: 15 , oral & $\begin{array}{c}=\text { FLX: Sucrose preference, immobility time in FST, } \\
\text { immobility time in TST, serum CORT, hippocampal } \\
\text { BDNF }\end{array}$ \\
\hline Ge and colleagues, 2013 [21] & $\begin{array}{l}\text { CUMS-exposed male } \\
\text { Sprague-Dawley rats }\end{array}$ & 21 days & RSV: 15, i.p. FLX: 2, i.p. & $\begin{array}{l}\text { =FLX: Sucrose preference, immobility time in FST, } \\
\text { immobility time in TST, serum MDA, serum CORT } \\
\text { <FLX: CRH mRNA expression }\end{array}$ \\
\hline Huang and colleagues, 2013 [23] & male ICR mice & 4 days & $\begin{array}{l}\text { RSV: } 1.25,2.5,10,20,40,80 \text {, oral } \\
\text { + piperine: } 2.5 \text { i.p. FLX: } 10 \text { i.p. } \\
\text { Imipramine: } 10 \text { i.p. }\end{array}$ & $\begin{array}{c}=\text { FLX: Immobility time in FST }{ }^{(10 / 20)} \text {, immobility time in } \\
\text { TST }^{(10 / 20)}=\text { Imipramine: locomotor activity; } \\
\text { reserpine-induced hypothermia }{ }^{(10,20)} \text { and ptosis }{ }^{(20)} ; \text { FC } \\
\text { 5-HT }{ }^{(10,20)} \text {, norepinephrine }{ }^{(20)} \text {, dopamine }{ }^{(20)} \text {, and } \\
\text { 5-HIAA/5-HT ratio }{ }^{(20)}\end{array}$ \\
\hline Li and colleagues, 2016 [25] & $\begin{array}{l}\text { CORT-injected male ICR } \\
\text { mice }\end{array}$ & 21 days & RSV: 50,100 , oral FLX: 20 , oral & $\begin{array}{c}=\text { FLX: Sucrose preference }{ }^{(50 / 100)}, \text { immobility time in } \\
\text { FST }{ }^{(50 / 100)}, \text { CORT }^{(50 / 100)}\end{array}$ \\
\hline Liu and colleagues, 2014 [26] & $\begin{array}{l}\text { CUMS-exposed male } \\
\text { Wistar rats }\end{array}$ & 5 weeks & RSV: 20, 40, 80, i.p. DES: 10, i.p. & $\begin{array}{l}=\text { sucrose preference }(20 / 40 / 80) \text {, immobility time in FST } \\
(40 / 80), \text { crossing and grooming in OFT }{ }^{(80)} \text {, serum CORT } \\
(80) \text { BDNF in hippocampus }{ }^{(80)} \text { and amygdala }(40 / 80), \\
\text { p-CREB in hippocampus }{ }^{(80)} \text { and amygdala }(80), \text { p-ERK } \\
\text { in hippocampus }{ }^{(40 / 80)} \text { and amygdala }{ }^{(40 / 80)}\end{array}$ \\
\hline Liu and colleagues, 2016 [28] & $\begin{array}{l}\text { CUMS-exposed male } \\
\text { Wistar rats }\end{array}$ & 4 weeks & RSV: 80, i.p. Ketamine: 20, i.p & $\begin{array}{l}\text { =Ketamine: Sucrose preference; immobility time in FST; } \\
\text { OFT; PFC and hippocampal MDA and SOD; } \\
\text { phosphoylated mTOR and Akt }\end{array}$ \\
\hline López and colleagues, 2014 [29] & male CD1 mice & $<1$ day & $\begin{array}{l}\text { RSV: } 2.5,5,10 \text {, i.p. buproprion: } \\
10 \text { i.p. citalopram: } 20 \text { i.p. } \\
\text { desipramine: } 35 \text { i.p. } \\
\text { imipramine: } 35 \text { i.p. } \\
\text { moclobemide: } 35 \text { i.p. nisoxetine: } \\
2.5 \text { i.p. nomifensine: } 2.5 \text { i.p. }\end{array}$ & $\downarrow$ immobility time in FST ${ }^{(10)}$ \\
\hline
\end{tabular}


Table 2. Cont

\begin{tabular}{|c|c|c|c|c|}
\hline Author, Year & Animal Model & Txt Duration & Dosages (mg/kg/Day) & Comparative Effectiveness of RSV \\
\hline Pang and colleagues, 2015 [30] & $\begin{array}{l}\text { middle cerebral artery } \\
\text { occluded male } \\
\text { Sprague-Dawley rats }\end{array}$ & 14 days & $\begin{array}{c}\text { RSV: } 10,20,40 \text {, oral Imipramine: } \\
10 \text { i.p. }\end{array}$ & $\begin{array}{l}\text { =Imipramine: Sucrose preference }{ }^{(20 / 40)} \text {; FST }(20 / 40) \\
\text { CRF expression in hypothalamus }(20 / 40) \text {, hippocampus } \\
(20 / 40) \text { and FC }(20 / 40) ; \text { GR expression in hypothalamus } \\
(40), \text { hippocampus }(20 / 40) \text {, and FC }{ }^{(20 / 40)} \text {; BDNF } \\
\text { expression in hypothalamus }{ }^{(40)} \text {, hippocampus }{ }^{(20 / 40)} \\
\text { and FC }{ }^{(40)}<\text { Imipramine: adrenal gland index }\end{array}$ \\
\hline Sakr and colleagues, 2015 [31] & $\begin{array}{l}\text { CUMS-exposed male } \\
\text { Sprague-Dawley rats }\end{array}$ & 28 days & RSV: 20, oral FLX: 10, oral & $\begin{array}{c}\text { >FLX: MDA, SOD, CAT, GSH <FLX: Sucrose preference, } \\
\text { immobility time in FST, serum testosterone, serum } \\
\text { CORT, hippocampal 5-HT }\end{array}$ \\
\hline Wang and colleagues, 2013 [32] & male Kunming mice & 21 days & RSV: $20,40,80$, i.p. FLX: 10, i.p. & $\begin{array}{l}=\text { FLX: Immobility time in FST }(20 / 40 / 80) \text {, immobility } \\
\text { time in TST }(20 / 40 / 80) \text {, serum CORT }(80), \text { BDNF mRNA in } \\
\text { hippocampus }{ }^{(40 / 80)} \text { and PFC }(20 / 40 / 80) \text {, BDNF protein } \\
\text { expression in hippocampus }{ }^{(20 / 40 / 80)} \text { and PFC }{ }^{(20 / 40 / 80)}\end{array}$ \\
\hline Wang and colleagues, 2016 [33] & $\begin{array}{l}\text { CRS-exposed male } \\
\text { Wistar rats }\end{array}$ & 21 days & RSV: 80, i.p. FLX: 10, i.p. & $\begin{array}{l}=\text { FLX: Sucrose preference; immobility time in FST; OFT; } \\
\text { hippocampal and PFC BDNF mRNA and protein } \\
\text { expression; hippocampal and PFC phosphorylated ERK } \\
\text { mRNA and protein expression }\end{array}$ \\
\hline Xu and colleagues, 2010 [7] & male ICR mice & 4 days & $\begin{array}{l}\text { RSV: } 20,40,80 \text {, i.g. FLX: } 10 \text {, i.p. } \\
\text { Moclobemide: } 20 \text {, i.p. } \\
\text { Imipramine: } 20 \text {, i.p. }\end{array}$ & 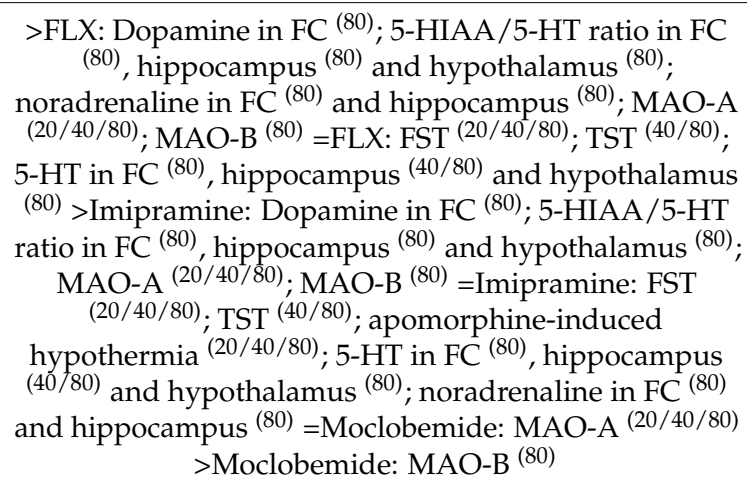 \\
\hline
\end{tabular}


Animal models of depression are at best imperfect analogues of clinical depression, and therefore caution must be exercised when extrapolating the results of animal studies to humans. Wine shows more positive effects on mood than other alcoholic beverages-however, the large number of components in wine makes it difficult to determine whether resveratrol was responsible for the beneficial effects [92]. Few studies have specifically examined the effects of resveratrol on depression in humans, although several studies have measured mood following resveratrol treatment [93-97]. Two of those studies found no significant differences in any measure of mood [17,96,97], and one found reduced anxiety following resveratrol treatment, but no changes in depression or other mood components [94]. The lack of significance in the latter study may have resulted from the resveratrol dosage, which was lower in proportion to body weight than the dosages used in most animal studies. Unfortunately, these studies have limited relevance to this review because at baseline the subjects were healthy adults who were not experiencing depressive symptoms. The trial by Davinelli et al. was conducted in postmenopausal women [93]. At baseline, depression was reported by many subjects, but not all, as depression was only one of several symptoms used as inclusion criteria. Compared with the placebo, resveratrol significantly reduced depressive symptoms as measured by the Hamilton Rating Scale for Depression (HAM-D). In patients with Minimal Hepatic Encephalopathy (MHE), resveratrol treatment was also associated with decreased depression as measured by the Beck Depression Inventory [93]. In light of this limited evidence, more controlled clinical studies are needed to elucidate resveratrol's antidepressant effects in humans.

In conclusion, resveratrol exhibited positive effects in animal models of depression comparable to the effects of several pharmaceutical antidepressants. Although these findings cannot be generalized to humans, results in animal models delineate the potential for resveratrol to serve as a natural antidepressant. Resveratrol's excellent safety profile and limited side effects make it an appealing option for depression patients, either as an alternative or adjuvant to conventional therapies. The studies discussed in this review focused on various biological mechanisms, but it is likely that these mechanisms work in concert with one another. Because resveratrol affected many brain regions and neural pathways, this polyphenol may be beneficial in many cases of depression, even if the underlying causes are heterogeneous. Based on the present review, resveratrol merits further investigation as a possible therapeutic agent for the treatment of depression.

Author Contributions: Writing-Original Draft Preparation: A.M.; Writing—Review \& Editing: M.Y.H.; Writing-Review \& Editing: J.B.

Conflicts of Interest: Authors have no conflict of interest.

\section{References}

1. Depression Fact Sheet. Available online: http://www.who.int/mediacentre/factsheets/fs369/en/ (accessed on 15 August 2018).

2. Collins, P.Y.; Patel, V.; Joestl, S.S.; March, D.; Insel, T.R.; Daar, A.S.; Bordin, I.A.; Costello, E.J.; Durkin, M.; Fairburn, C.; et al. Grand challenges in global mental health. Nature 2011, 475, 27-30. [CrossRef] [PubMed]

3. Pratt, L.A.; Brody, D.J.; Gu, Q. Antidepressant Use in Persons Aged 12 and over: United States, 2005-2008; US Department of Health and Human Services, Centers for Disease Control, NCHS Data Brief: Hyattsville, MD, USA, 2011; pp. 1-7.

4. National Center for Health Statistics. Health, United States, 2010: With Special Feature on Death and Dying; U.S. Government Printing Office: Washington, DC, USA, 2011; p. 107. Available online: https://www.cdc.gov/ nchs/data/hus/hus10.pdf\#074 (accessed on 15 August 2018).

5. Liu, L.; Zhang, Q.; Cai, Y.; Sun, D.; He, X.; Wang, L.; Yu, D.; Li, X.; Xiong, X.; Xu, H.; et al. Resveratrol counteracts lipopolysaccharide-induced depressive-like behaviors via enhanced hippocampal neurogenesis. Oncotarget 2016, 7, 56045-56059. [CrossRef] [PubMed]

6. Hurley, L.L.; Akinfiresoye, L.; Kalejaiye, O.; Tizabi, Y. Antidepressant effects of resveratrol in an animal model of depression. Behav. Brain Res. 2014, 268, 1-7. [CrossRef] [PubMed] 
7. Xu, Y.; Wang, Z.; You, W.; Zhang, X.; Li, S.; Barish, P.A.; Vernon, M.M.; Du, X.; Li, G.; Pan, J.; et al. Antidepressant-like effect of trans-resveratrol: Involvement of serotonin and noradrenaline system. Eur. Neuropsychopharm. 2010, 20, 405-413. [CrossRef] [PubMed]

8. Ferguson, J.M. Ssri antidepressant medications: Adverse effects and tolerability. Prim. Care Companion J. Clin. Psychiatry 2001, 3, 22-27. [CrossRef] [PubMed]

9. Nabavi, S.M.; Daglia, M.; Braidy, N.; Nabavi, S.F. Natural products, micronutrients, and nutraceuticals for the treatment of depression: A short review. Nutr. Neurosci. 2017, 20, 180-194. [CrossRef] [PubMed]

10. Gambini, J.; Ingles, M.; Olaso, G.; Lopez-Grueso, R.; Bonet-Costa, V.; Gimeno-Mallench, L.; Mas-Bargues, C.; Abdelaziz, K.M.; Gomez-Cabrera, M.C.; Vina, J.; et al. Properties of resveratrol: In vitro and in vivo studies about metabolism, bioavailability, and biological effects in animal models and humans. Oxid. Med. Cell. Longev. 2015, 2015, 837042. [CrossRef] [PubMed]

11. Quincozes-Santos, A.; Bobermin, L.D.; Latini, A.; Wajner, M.; Souza, D.O.; Goncalves, C.A.; Gottfried, C. Resveratrol protects $\mathrm{c} 6$ astrocyte cell line against hydrogen peroxide-induced oxidative stress through heme oxygenase 1. PLoS ONE 2013, 8, e64372. [CrossRef] [PubMed]

12. Malhotra, A.; Bath, S.; Elbarbry, F. An organ system approach to explore the antioxidative, anti-inflammatory, and cytoprotective actions of resveratrol. Oxid. Med. Cell. Longev. 2015, 2015, 803971. [CrossRef] [PubMed]

13. Rege, S.D.; Geetha, T.; Griffin, G.D.; Broderick, T.L.; Babu, J.R. Neuroprotective effects of resveratrol in alzheimer disease pathology. Front. Aging Neurosci. 2014, 6, 218. [CrossRef] [PubMed]

14. Wightman, E.L.; Haskell-Ramsay, C.F.; Reay, J.L.; Williamson, G.; Dew, T.; Zhang, W.; Kennedy, D.O. The effects of chronic trans-resveratrol supplementation on aspects of cognitive function, mood, sleep, health and cerebral blood flow in healthy, young humans. Br. J. Nutr. 2015, 114, 1427-1437. [CrossRef] [PubMed]

15. Wu, R.E.; Huang, W.C.; Liao, C.C.; Chang, Y.K.; Kan, N.W.; Huang, C.C. Resveratrol protects against physical fatigue and improves exercise performance in mice. Molecules 2013, 18, 4689-4702. [CrossRef] [PubMed]

16. Ge, J.F.; Xu, Y.Y.; Qin, G.; Cheng, J.Q.; Chen, F.H. Resveratrol ameliorates the anxiety- and depression-like behavior of subclinical hypothyroidism rat: Possible involvement of the hpt axis, hpa axis, and wnt/beta-catenin pathway. Front. Endocrinol. (Lausanne) 2016, 7, 44. [CrossRef] [PubMed]

17. Ahmed, R.F.; Abdel-Rahman, R.F.; Farid, O.A.H.A.; El-Marasy, S.A.; Hessin, A.F. Combined hepatoprotective and antidepressant effects of resveratrol in an acute model of depression. Bull. Fac. Pharm. Cairo Univ. 2014, 52, 191-197. [CrossRef]

18. Ali, S.H.; Madhana, R.M.; Athira, K.V.; Kasala, E.R.; Bodduluru, L.N.; Pitta, S.; Mahareddy, J.R.; Lahkar, M. Resveratrol ameliorates depressive-like behavior in repeated corticosterone-induced depression in mice. Steroids 2015, 101, 37-42. [CrossRef] [PubMed]

19. Chen, W.J.; Du, J.K.; Hu, X.; Yu, Q.; Li, D.X.; Wang, C.N.; Zhu, X.Y.; Liu, Y.J. Protective effects of resveratrol on mitochondrial function in the hippocampus improves inflammation-induced depressive-like behavior. Physiol. Behav. 2017, 182, 54-61. [CrossRef] [PubMed]

20. Finnell, J.E.; Lombard, C.M.; Melson, M.N.; Singh, N.P.; Nagarkatti, M.; Nagarkatti, P.; Fadel, J.R.; Wood, C.S.; Wood, S.K. The protective effects of resveratrol on social stress-induced cytokine release and depressive-like behavior. Brain Behav. Immun. 2017, 59, 147-157. [CrossRef] [PubMed]

21. Ge, J.F.; Peng, L.; Cheng, J.Q.; Pan, C.X.; Tang, J.; Chen, F.H.; Li, J. Antidepressant-like effect of resveratrol: Involvement of antioxidant effect and peripheral regulation on hpa axis. Pharmacol. Biochem. Behav. 2013, 114-115, 64-69. [CrossRef] [PubMed]

22. Ge, L.; Liu, L.; Liu, H.; Liu, S.; Xue, H.; Wang, X.; Yuan, L.; Wang, Z.; Liu, D. Resveratrol abrogates lipopolysaccharide-induced depressive-like behavior, neuroinflammatory response, and creb/bdnf signaling in mice. Eur. J. Pharmacol. 2015, 768, 49-57. [CrossRef] [PubMed]

23. Huang, W.; Chen, Z.; Wang, Q.; Lin, M.; Wu, S.; Yan, Q.; Wu, F.; Yu, X.; Xie, X.; Li, G.; et al. Piperine potentiates the antidepressant-like effect of trans-resveratrol: Involvement of monoaminergic system. Metab. Brain Dis. 2013, 28, 585-595. [CrossRef] [PubMed]

24. Kodali, M.; Parihar, V.K.; Hattiangady, B.; Mishra, V.; Shuai, B.; Shetty, A.K. Resveratrol prevents age-related memory and mood dysfunction with increased hippocampal neurogenesis and microvasculature, and reduced glial activation. Sci. Rep. 2015, 5, 8075. [CrossRef] [PubMed]

25. Li, Y.-C.; Liu, Y.-M.; Shen, J.-D.; Chen, J.-J.; Pei, Y.-Y.; Fang, X.-Y. Resveratrol ameliorates the depressive-like behaviors and metabolic abnormalities induced by chronic corticosterone injection. Molecules 2016, 21, 1341. [CrossRef] [PubMed] 
26. Liu, D.; Xie, K.; Yang, X.; Gu, J.; Ge, L.; Wang, X.; Wang, Z. Resveratrol reverses the effects of chronic unpredictable mild stress on behavior, serum corticosterone levels and bdnf expression in rats. Behav. Brain Res. 2014, 264, 9-16. [CrossRef] [PubMed]

27. Liu, D.; Zhang, Q.; Gu, J.; Wang, X.; Xie, K.; Xian, X.; Wang, J.; Jiang, H.; Wang, Z. Resveratrol prevents impaired cognition induced by chronic unpredictable mild stress in rats. Prog. Neuropsychopharmacol. Biol. Psychiatry 2014, 49, 21-29. [CrossRef] [PubMed]

28. Liu, S.; Li, T.; Liu, H.; Wang, X.; Bo, S.; Xie, Y.; Bai, X.; Wu, L.; Wang, Z.; Liu, D. Resveratrol exerts antidepressant properties in the chronic unpredictable mild stress model through the regulation of oxidative stress and mtor pathway in the rat hippocampus and prefrontal cortex. Behav. Brain Res. 2016, 302, 191-199. [CrossRef] [PubMed]

29. López, M.C.; Fontenla, J.A.; Uriarte, E.; Santana, L.; Sobarzo-Sánchez, E. Comparison of the antidepressive effects of trans-resveratrol and 5-methoxy-7h-dibenzo[de,h]quinolin-7-one. Curr. Top. Med. Chem. 2014, 14, 234-238. [CrossRef] [PubMed]

30. Pang, C.; Cao, L.; Wu, F.; Wang, L.; Wang, G.; Yu, Y.; Zhang, M.; Chen, L.; Wang, W.; Lv, W.; et al. The effect of trans-resveratrol on post-stroke depression via regulation of hypothalamus-pituitary-adrenal axis. Neuropharmacology 2015, 97, 447-456. [CrossRef] [PubMed]

31. Sakr, H.F.; Abbas, A.M.; Elsamanoudy, A.Z.; Ghoneim, F.M. Effect of fluoxetine and resveratrol on testicular functions and oxidative stress in a rat model of chronic mild stress-induced depression. J. Physiol. Pharmacol. 2015, 66, 515-527. [PubMed]

32. Wang, Z.; Gu, J.; Wang, X.; Xie, K.; Luan, Q.; Wan, N.; Zhang, Q.; Jiang, H.; Liu, D. Antidepressant-like activity of resveratrol treatment in the forced swim test and tail suspension test in mice: The hpa axis, bdnf expression and phosphorylation of erk. Pharmacol. Biochem. Behav. 2013, 112, 104-110. [CrossRef] [PubMed]

33. Wang, X.; Xie, Y.; Zhang, T.; Bo, S.; Bai, X.; Liu, H.; Li, T.; Liu, S.; Zhou, Y.; Cong, X.; et al. Resveratrol reverses chronic restraint stress-induced depression-like behaviour: Involvement of bdnf level, erk phosphorylation and expression of bcl-2 and bax in rats. Brain Res. Bull. 2016, 125, 134-143. [CrossRef] [PubMed]

34. Wang, F.; Wang, J.; An, J.; Yuan, G.; Hao, X.; Zhang, Y. Resveratrol ameliorates depressive disorder through the netrin1-mediated extracellular signal-regulated kinase/camp signal transduction pathway. Mol. Med. Rep. 2018, 17, 4611-4618. [PubMed]

35. Steru, L.; Chermat, R.; Thierry, B.; Simon, P. The tail suspension test: A new method for screening antidepressants in mice. Psychopharmacology (Berl.) 1985, 85, 367-370. [CrossRef] [PubMed]

36. Yin, X.; Guven, N.; Dietis, N. Stress-based animal models of depression: Do we actually know what we are doing? Brain Res. 2016, 1652, 30-42. [CrossRef] [PubMed]

37. Du, X.; Pang, T.Y. Is dysregulation of the hpa-axis a core pathophysiology mediating co-morbid depression in neurodegenerative diseases? Front. Psychiatry 2015, 6, 32. [CrossRef] [PubMed]

38. Lok, A.; Mocking, R.J.; Ruhe, H.G.; Visser, I.; Koeter, M.W.; Assies, J.; Bockting, C.L.; Olff, M.; Schene, A.H. Longitudinal hypothalamic-pituitary-adrenal axis trait and state effects in recurrent depression. Psychoneuroendocrinology 2012, 37, 892-902. [CrossRef] [PubMed]

39. Vythilingam, M.; Vermetten, E.; Anderson, G.M.; Luckenbaugh, D.; Anderson, E.R.; Snow, J.; Staib, L.H.; Charney, D.S.; Bremner, J.D. Hippocampal volume, memory, and cortisol status in major depressive disorder: Effects of treatment. Biol. Psychiatry 2004, 56, 101-112. [CrossRef] [PubMed]

40. Slavich, G.M.; Irwin, M.R. From stress to inflammation and major depressive disorder: A social signal transduction theory of depression. Psychol. Bull. 2014, 140, 774-815. [CrossRef] [PubMed]

41. Felger, J.C.; Lotrich, F.E. Inflammatory cytokines in depression: Neurobiological mechanisms and therapeutic implications. Neuroscience 2013, 246, 199-229. [CrossRef] [PubMed]

42. Lull, M.E.; Block, M.L. Microglial activation and chronic neurodegeneration. Neurotherapeutics 2010, 7, 354-365. [CrossRef] [PubMed]

43. Lopresti, A.L.; Maker, G.L.; Hood, S.D.; Drummond, P.D. A review of peripheral biomarkers in major depression: The potential of inflammatory and oxidative stress biomarkers. Prog. Neuropsychopharmacol. Biol. Psychiatry 2014, 48, 102-111. [CrossRef] [PubMed]

44. Xia, N.; Daiber, A.; Forstermann, U.; Li, H. Antioxidant effects of resveratrol in the cardiovascular system. Br. J. Pharmacol. 2017, 174, 1633-1646. [CrossRef] [PubMed] 
45. Colaianna, M.; Tucci, P.; Zotti, M.; Morgese, M.G.; Schiavone, S.; Govoni, S.; Cuomo, V.; Trabace, L. Soluble beta amyloid(1-42): A critical player in producing behavioural and biochemical changes evoking depressive-related state? Br. J. Pharmacol. 2010, 159, 1704-1715. [CrossRef] [PubMed]

46. Feng, Y.; Wang, X.P.; Yang, S.G.; Wang, Y.J.; Zhang, X.; Du, X.T.; Sun, X.X.; Zhao, M.; Huang, L.; Liu, R.T. Resveratrol inhibits beta-amyloid oligomeric cytotoxicity but does not prevent oligomer formation. Neurotoxicology 2009, 30, 986-995. [CrossRef] [PubMed]

47. Han, Y.S.; Zheng, W.H.; Bastianetto, S.; Chabot, J.G.; Quirion, R. Neuroprotective effects of resveratrol against beta-amyloid-induced neurotoxicity in rat hippocampal neurons: Involvement of protein kinase $\mathrm{c}$. Br. J. Pharmacol. 2004, 141, 997-1005. [CrossRef] [PubMed]

48. Jang, J. Protective effect of resveratrol on $\beta$-amyloid-induced oxidative pc12 cell death. Free Radic. Biol. Med. 2003, 34, 1100-1110. [CrossRef]

49. Marambaud, P.; Zhao, H.; Davies, P. Resveratrol promotes clearance of alzheimer's disease amyloid-beta peptides. J. Biol. Chem. 2005, 280, 37377-37382. [CrossRef] [PubMed]

50. Dwivedi, Y. Involvement of brain-derived neurotrophic factor in late-life depression. Am. J. Geriatr. Psychiatry 2013, 21, 433-449. [CrossRef] [PubMed]

51. Smith, M.A.; Makino, S.; Kvetnansky, R.; Post, R.M. Stress and glucocorticoids affect the expression of brain-derived neurotrophic factor and neurotrophin-3 mrnas in the hippocampus. J. Neurosci. 1995, 15, 1768-1777. [CrossRef] [PubMed]

52. Schaaf, M.J.; De Kloet, E.R.; Vreugdenhil, E. Corticosterone effects on bdnf expression in the hippocampus. Implications for memory formation. Stress 2000, 3, 201-208. [CrossRef] [PubMed]

53. Dwivedi, Y.; Rizavi, H.S.; Pandey, G.N. Antidepressants reverse corticosterone-mediated decrease in brain-derived neurotrophic factor expression: Differential regulation of specific exons by antidepressants and corticosterone. Neuroscience 2006, 139, 1017-1029. [CrossRef] [PubMed]

54. Xue, W.; Wang, W.; Gong, T.; Zhang, H.; Tao, W.; Xue, L.; Sun, Y.; Wang, F.; Chen, G. Pka-creb-bdnf signaling regulated long lasting antidepressant activities of yueju but not ketamine. Sci. Rep. 2016, 6, 26331. [CrossRef] [PubMed]

55. Nibuya, M.; Nestler, E.J.; Duman, R.S. Chronic antidepressant administration increases the expression of camp response element binding protein (creb) in rat hippocampus. J. Neurosci. 1996, 16, 2365-2372. [CrossRef] [PubMed]

56. Pinnock, S.B.; Blake, A.M.; Platt, N.J.; Herbert, J. The roles of bdnf, pcreb and wnt3a in the latent period preceding activation of progenitor cell mitosis in the adult dentate gyrus by fluoxetine. PLoS ONE 2010, 5, e13652. [CrossRef] [PubMed]

57. Conti, A.C.; Cryan, J.F.; Dalvi, A.; Lucki, I.; Blendy, J.A. Camp response element-binding protein is essential for the upregulation of brain-derived neurotrophic factor transcription, but not the behavioral or endocrine responses to antidepressant drugs. J. Neurosci. 2002, 22, 3262-3268. [CrossRef] [PubMed]

58. Dwivedi, Y.; Zhang, H. Altered erk1/2 signaling in the brain of learned helpless rats: Relevance in vulnerability to developing stress-induced depression. Neural Plast. 2016, 2016, 7383724. [CrossRef] [PubMed]

59. Dwivedi, Y.; Rizavi, H.S.; Roberts, R.C.; Conley, R.C.; Tamminga, C.A.; Pandey, G.N. Reduced activation and expression of erk1/2 map kinase in the post-mortem brain of depressed suicide subjects. J. Neurochem. 2001, 77, 916-928. [CrossRef] [PubMed]

60. First, M.; Gil-Ad, I.; Taler, M.; Tarasenko, I.; Novak, N.; Weizman, A. The effects of fluoxetine treatment in a chronic mild stress rat model on depression-related behavior, brain neurotrophins and erk expression. J. Mol. Neurosci. 2011, 45, 246-255. [CrossRef] [PubMed]

61. First, M.; Gil-Ad, I.; Taler, M.; Tarasenko, I.; Novak, N.; Weizman, A. The effects of reboxetine treatment on depression-like behavior, brain neurotrophins, and erk expression in rats exposed to chronic mild stress. J. Mol. Neurosci. 2013, 50, 88-97. [CrossRef] [PubMed]

62. Abelaira, H.M.; Reus, G.Z.; Neotti, M.V.; Quevedo, J. The role of mtor in depression and antidepressant responses. Life Sci. 2014, 101, 10-14. [CrossRef] [PubMed]

63. Chandran, A.; Iyo, A.H.; Jernigan, C.S.; Legutko, B.; Austin, M.C.; Karolewicz, B. Reduced phosphorylation of the mtor signaling pathway components in the amygdala of rats exposed to chronic stress. Prog. Neuropsychopharmacol. Biol. Psychiatry 2013, 40, 240-245. [CrossRef] [PubMed] 
64. Lie, D.C.; Colamarino, S.A.; Song, H.J.; Desire, L.; Mira, H.; Consiglio, A.; Lein, E.S.; Jessberger, S.; Lansford, H.; Dearie, A.R.; et al. Wnt signalling regulates adult hippocampal neurogenesis. Nature 2005, 437, 1370-1375. [CrossRef] [PubMed]

65. Hussaini, S.M.; Choi, C.I.; Cho, C.H.; Kim, H.J.; Jun, H.; Jang, M.H. Wnt signaling in neuropsychiatric disorders: Ties with adult hippocampal neurogenesis and behavior. Neurosci. Biobehav. Rev. 2014, 47, 369-383. [CrossRef] [PubMed]

66. Okerlund, N.D.; Cheyette, B.N. Synaptic wnt signaling-a contributor to major psychiatric disorders? J. Neurodev. Disord. 2011, 3, 162-174. [CrossRef] [PubMed]

67. Brand, S.J.; Moller, M.; Harvey, B.H. A review of biomarkers in mood and psychotic disorders: A dissection of clinical vs. Preclinical correlates. Curr. Neuropharmacol. 2015, 13, 324-368. [CrossRef] [PubMed]

68. Berton, O.; Nestler, E.J. New approaches to antidepressant drug discovery: Beyond monoamines. Nat. Rev. Neurosci. 2006, 7, 137-151. [CrossRef] [PubMed]

69. Tye, K.M.; Mirzabekov, J.J.; Warden, M.R.; Ferenczi, E.A.; Tsai, H.C.; Finkelstein, J.; Kim, S.Y.; Adhikari, A.; Thompson, K.R.; Andalman, A.S.; et al. Dopamine neurons modulate neural encoding and expression of depression-related behaviour. Nature 2013, 493, 537-541. [CrossRef] [PubMed]

70. Sarubbo, F.; Ramis, M.R.; Aparicio, S.; Ruiz, L.; Esteban, S.; Miralles, A.; Moranta, D. Improving effect of chronic resveratrol treatment on central monoamine synthesis and cognition in aged rats. Age (Dordr.) 2015, 37, 9777. [CrossRef] [PubMed]

71. Gartside, S.E.; Leitch, M.M.; McQuade, R.; Swarbrick, D.J. Flattening the glucocorticoid rhythm causes changes in hippocampal expression of messenger rnas coding structural and functional proteins: Implications for aging and depression. Neuropsychopharmacology 2003, 28, 821-829. [CrossRef] [PubMed]

72. Jarcho, M.R.; Slavich, G.M.; Tylova-Stein, H.; Wolkowitz, O.M.; Burke, H.M. Dysregulated diurnal cortisol pattern is associated with glucocorticoid resistance in women with major depressive disorder. Biol. Psychol. 2013, 93, 150-158. [CrossRef] [PubMed]

73. Zhu, L.J.; Liu, M.Y.; Li, H.; Liu, X.; Chen, C.; Han, Z.; Wu, H.Y.; Jing, X.; Zhou, H.H.; Suh, H.; et al. The different roles of glucocorticoids in the hippocampus and hypothalamus in chronic stress-induced hpa axis hyperactivity. PLoS ONE 2014, 9, e97689. [CrossRef] [PubMed]

74. Abreu, M.S.; Koakoski, G.; Ferreira, D.; Oliveira, T.A.; Rosa, J.G.; Gusso, D.; Giacomini, A.C.; Piato, A.L.; Barcellos, L.J. Diazepam and fluoxetine decrease the stress response in zebrafish. PLoS ONE 2014, 9, e103232. [CrossRef] [PubMed]

75. Jeon, S.W.; Kim, Y.K. Neuroinflammation and cytokine abnormality in major depression: Cause or consequence in that illness? World J. Psychiatry 2016, 6, 283-293. [CrossRef] [PubMed]

76. Besedovsky, H.O.; del Rey, A. The cytokine-hpa axis feed-back circuit. Z. Rheumatol. 2000, 59 (Suppl. 2), II/26-II/30. [CrossRef]

77. Busch, F.; Mobasheri, A.; Shayan, P.; Lueders, C.; Stahlmann, R.; Shakibaei, M. Resveratrol modulates interleukin-1beta-induced phosphatidylinositol 3-kinase and nuclear factor kappab signaling pathways in human tenocytes. J. Biol. Chem. 2012, 287, 38050-38063. [CrossRef] [PubMed]

78. Palta, P.; Samuel, L.J.; Miller, E.R.; Szanton, S.L. Depression and oxidative stress: Results from a meta-analysis of observational studies. Psychosom. Med. 2014, 76, 12-19. [CrossRef] [PubMed]

79. Shelton, R.C.; Claiborne, J.; Sidoryk-Wegrzynowicz, M.; Reddy, R.; Aschner, M.; Lewis, D.A.; Mirnics, K. Altered expression of genes involved in inflammation and apoptosis in frontal cortex in major depression. Mol. Psychiatry 2011, 16, 751-762. [CrossRef] [PubMed]

80. Bakunina, N.; Pariante, C.M.; Zunszain, P.A. Immune mechanisms linked to depression via oxidative stress and neuroprogression. Immunology 2015, 144, 365-373. [CrossRef] [PubMed]

81. Ledo, J.H.; Azevedo, E.P.; Beckman, D.; Ribeiro, F.C.; Santos, L.E.; Razolli, D.S.; Kincheski, G.C.; Melo, H.M.; Bellio, M.; Teixeira, A.L.; et al. Cross talk between brain innate immunity and serotonin signaling underlies depressive-like behavior induced by alzheimer's amyloid-beta oligomers in mice. J. Neurosci. 2016, 36, 12106-12116. [CrossRef] [PubMed]

82. Ledo, J.H.; Azevedo, E.P.; Clarke, J.R.; Ribeiro, F.C.; Figueiredo, C.P.; Foguel, D.; De Felice, F.G.; Ferreira, S.T. Amyloid-beta oligomers link depressive-like behavior and cognitive deficits in mice. Mol. Psychiatry 2013, 18, 1053-1054. [CrossRef] [PubMed]

83. Swardfager, W.; Lanctot, K.; Rothenburg, L.; Wong, A.; Cappell, J.; Herrmann, N. A meta-analysis of cytokines in alzheimer's disease. Biol. Psychiatry 2010, 68, 930-941. [CrossRef] [PubMed] 
84. Morgese, M.G.; Tucci, P.; Colaianna, M.; Zotti, M.; Cuomo, V.; Schiavone, S.; Trabace, L. Modulatory activity of soluble beta amyloid on hpa axis function in rats. Curr. Pharm. Des. 2014, 20, 2539-2546. [CrossRef] [PubMed]

85. Duman, R.S. Role of neurotrophic factors in the etiology and treatment of mood disorders. Neuromol. Med. 2004, 5, 11-25. [CrossRef]

86. Park, H.R.; Kong, K.H.; Yu, B.P.; Mattson, M.P.; Lee, J. Resveratrol inhibits the proliferation of neural progenitor cells and hippocampal neurogenesis. J. Biol. Chem. 2012, 287, 42588-42600. [CrossRef] [PubMed]

87. Schoenfeld, T.J.; Cameron, H.A. Adult neurogenesis and mental illness. Neuropsychopharmacology 2015, 40, 113-128. [CrossRef] [PubMed]

88. Neto, F.L.; Borges, G.; Torres-Sanchez, S.; Mico, J.A.; Berrocoso, E. Neurotrophins role in depression neurobiology: A review of basic and clinical evidence. Curr. Neuropharmacol. 2011, 9, 530-552. [CrossRef] [PubMed]

89. Young, C.B.; Chen, T.; Nusslock, R.; Keller, J.; Schatzberg, A.F.; Menon, V. Anhedonia and general distress show dissociable ventromedial prefrontal cortex connectivity in major depressive disorder. Transl. Psychiatry 2016, 6, e810. [CrossRef] [PubMed]

90. Nair, A.B.; Jacob, S. A simple practice guide for dose conversion between animals and human. J. Basic Clin. Pharm. 2016, 7, 27-31. [CrossRef] [PubMed]

91. Dalla, C.; Pitychoutis, P.M.; Kokras, N.; Papadopoulou-Daifoti, Z. Sex differences in animal models of depression and antidepressant response. Basic Clin. Pharmacol. Toxicol. 2010, 106, 226-233. [CrossRef] [PubMed]

92. Gea, A.; Beunza, J.J.; Estruch, R.; Sanchez-Villegas, A.; Salas-Salvado, J.; Buil-Cosiales, P.; Gomez-Gracia, E.; Covas, M.I.; Corella, D.; Fiol, M.; et al. Alcohol intake, wine consumption and the development of depression: The predimed study. BMC Med. 2013, 11, 192. [CrossRef] [PubMed]

93. Davinelli, S.; Scapagnini, G.; Marzatico, F.; Nobile, V.; Ferrara, N.; Corbi, G. Influence of equol and resveratrol supplementation on health-related quality of life in menopausal women: A randomized, placebo-controlled study. Maturitas 2017, 96, 77-83. [CrossRef] [PubMed]

94. Evans, H.M.; Howe, P.R.; Wong, R.H. Effects of resveratrol on cognitive performance, mood and cerebrovascular function in post-menopausal women; a 14-week randomised placebo-controlled intervention trial. Nutrients 2017, 9, 27. [CrossRef] [PubMed]

95. Malaguarnera, G.; Pennisi, M.; Bertino, G.; Motta, M.; Borzi, A.M.; Vicari, E.; Bella, R.; Drago, F.; Malaguarnera, M. Resveratrol in patients with minimal hepatic encephalopathy. Nutrients 2018, 10, 329. [CrossRef] [PubMed]

96. Wightman, E.L.; Reay, J.L.; Haskell, C.F.; Williamson, G.; Dew, T.P.; Kennedy, D.O. Effects of resveratrol alone or in combination with piperine on cerebral blood flow parameters and cognitive performance in human subjects: A randomised, double-blind, placebo-controlled, cross-over investigation. Br. J. Nutr. 2014, 112, 203-213. [CrossRef] [PubMed]

97. Witte, A.V.; Kerti, L.; Margulies, D.S.; Floel, A. Effects of resveratrol on memory performance, hippocampal functional connectivity, and glucose metabolism in healthy older adults. J. Neurosci. 2014, 34, 7862-7870. [CrossRef] [PubMed]

(C) 2018 by the authors. Licensee MDPI, Basel, Switzerland. This article is an open access article distributed under the terms and conditions of the Creative Commons Attribution (CC BY) license (http://creativecommons.org/licenses/by/4.0/). 